Departamento de Historia

Universidad de Santiago de Chile

Revista de Historia Social

y de las Mentalidades

Volumen 24, N¹, 2020: 169-206

Issn On Line: 0719-4749

\title{
SUSANA FIORITO Y EL ARCHIVO DE LOS CORDOBAZOS, DEL CLASISMO Y DE LA NUEVA IZQUIERDA*
}

\author{
SUSANA FIORITO AND THE ARCHIVES OF CORDOBAZOS, \\ CLASSISM AND THE NEW LEFT
}

\author{
DR.C ADRIÁN CELENTANO** \\ Universidad Nacional de La Plata \\ La Plata, Argentina \\ Email: adriancelentano@gmail.com \\ Id-ORCID: 0000-0002-8315-5379
}

\begin{abstract}
RESUMEN
Las prácticas archivísticas y editoriales de Susana Fiorito, historiadora y militante de la nueva izquierda intelectual, constituyeron a partir de 1970 los materiales del Archivo del

Sindicato de Trabajadores de Concord. En este artículo nos interesa precisar el rol de Fiorito en la preservación de dichos materiales, identificar su interpretación de la historia de la clase trabajadora protagonista de los "Cordobazos", y analizar en la organización del archivo el registro de las divergencias entre los intelectuales sobre la relación de la militancia
\end{abstract}

\begin{abstract}
As from 1970, the archival and editorial practices of Susana Fiorito, a historian and activist of the new intellectual left, set up the materials of the Archivos del Sindicato de Trabajadores de Concord. In this article we aim at exploring Fiorito's role in the preservation of such materials, identifying her interpretation of working-class history, focusing on those protagonists of the Cordobazos, as well as analizying, within the organization of the archive, the record of divergences among intellectuals upon the
\end{abstract}

* $\quad$ Recibido: 26 de diciembre de 2019. Aprobado: 25 de marzo de 2020.

** Artículo científico. Una primera versión de este trabajo fue presentada como ponencia en las III Jornadas / II Congreso Internacional "Archivos personales en transición: de lo privado a lo público, de lo analógico a lo digital" organizado en abril de 2019 por el Centro de Documentación e Investigación de la Cultura de Izquierdas (CeDInCI), Argentina. Adrián Celentano integra el proyecto de investigación "Los años de la "nueva izquierda". Auge y cierre del ciclo de movilización” (H891), María Cristina Tortti (directora). Investigador del Instituto de Investigaciones de Humanidades y Ciencias Sociales de la Facultad de Humanidades y Ciencias de la Educación de la Universidad Nacional de La Plata (FaHCE-UNLP). 
obrera "clasista" con las organizaciones políticas de la nueva izquierda.

Palabras clave: Archivo; intelectuales; clasismo; nueva izquierda relationship of "clasista" workers activism with New Left political organizations.

Keywords: Archive; Intellectuals; Classism; New Left

Cómo citar: Celentano, Adrián. (2020). "Susana Fiorito y el archivo de los cordobazos, del clasismo y de la nueva izquierda". Revista Historia Social y de las Mentalidades, 24(1), 169-206. DOI: 10.35588/rhsm. v24i1.4301

\section{PRESENTACIÓN}

Creo que estaba tan identificada con esa historia que mi cuerpo reconocía los papeles, aunque mis ojos no leyeran las carátulas.

Entrevista a Susana Fiorito, 2009.

En este trabajo nos interesa analizar las prácticas archivísticas y editoriales que realizó la maestra, traductora y militante de la nueva izquierda intelectual Susana Fiorito (1928) con los materiales que actualmente integran el Archivo del Sindicato de Trabajadores de Concord (SiTraC). Fiorito nació en Buenos Aires en 1928, de niña desarrolló la avidez por la lectura y desde su juventud se ligó a la cultura de izquierdas, y luego tomó distancia de su familia perteneciente a las clases acomodadas. Primero cursó estudios de magisterio y luego se especializó en la traducción del francés. En 1953 integró el núcleo de la mítica revista Contorno (1953-1962) con los hermanos David e Ismael Viñas, Ramón Alcalde, Juan José Sebreli y Adelaida Gigli. Con ellos leyó intensamente a Simone de Beauvoir, aunque Fiorito no se considera feminista. Junto al grupo contornista, en 1958 adhirió al radicalismo intransigente y apoyó la candidatura a presidente de la nación de Arturo Frondizi (1958-1962), de quien fue funcionaria universitaria durante el primer año de mandato. Junto a Ismael Viñas, su pareja por entonces, difundió en la revista Política artículos sobre la historia de las huelgas obreras de 1920-1921 de Santa Cruz. A fines de 1958, Fiorito participó en Qué hacer. Periódico político. A los pocos meses rompió junto al grupo contornista con el presidente Frondizi por sus inesperadas concesiones a las petroleras estadounidenses y por la represión gubernamental sobre la clase obrera peronista. Entonces participó en la fundación del Movimiento de Liberación Nacional (MLN) y del periódico Liberación, dos instancias clave en la formación de la nueva izquierda intelectual (Terán). Como parte de la crítica al frondizismo, la editorial del MLN publicó en 1965 el 
libro de Fiorito y Eugenio Gastiazoro titulado Ferrocarriles ¿restructuración o entrega?.

Fiorito tuvo un papel clave en la generación del voluminoso archivo que nos ocupa. La mayor parte de sus documentos fueron editados y puestos a circular entre 1970 y 1974. Fiorito comenzó a conservarlos en el periodo en que colaboró con la Secretaría de Prensa del SiTraC (1970-1971), a cargo del obrero Rafael Clavero. En la tarea de reunión de los materiales, así como en la secretaría, contó con la ayuda del escritor Andrés Rivera (1928-2016), quien se había convertido en su pareja y militaba en el partido maoísta Vanguardia Comunista (VC) (Celentano, "La formación"). Ella logró insertarse en un mundo sindical y político que sistemáticamente relegaba a las mujeres a la secretaria de actas, aunque ellas integraran activamente el movimiento popular cordobés (Fulchieri). En lugar de escribir el libro de actas, intervino en la transcripción y producción de panfletos, periódicos sindicales, resoluciones de plenarios, mandatos escritos emanados de asambleas, convenios colectivos de trabajo, recortes periodísticos, manuscritos del sindicato, cartas de obreros, periódicos de los partidos de la nueva izquierda y materiales de las organizaciones estudiantiles.

Durante la última dictadura militar argentina (1976-1983), Fiorito convirtió su práctica archivística en un archivo obrero ordenado desde significativas marcas personales. Y toda esta experiencia de transcripción y producción le permitió elaborar dos libros de tirada masiva, en los que utilizó el seudónimo de Natalia Duval. En junio de 1974 apareció el fascículo Argentina: sindicatos y movimientos de masas, en la colección popular "Historia del Movimiento Obrero" que publicaba en Buenos Aires el Centro Editor de América Latina (CEAL). En 1988 compiló fuentes y las prologó en Los sindicatos clasistas: SiTraC (1970-1971), editado en la Biblioteca Política del CEAL.

El SiTraC, junto al Sindicato de Trabajadores de Materfer (SiTraM), representaba a los obreros de las grandes fábricas FIAT de Córdoba, instaladas en el Barrio Ferreyra. Desde marzo de 1970, después de la rebelión de las bases de 1969 y de la elección de una nueva conducción integrada por jóvenes obreros combativos, ambos sindicatos adoptaron métodos radicalizados. Con ellos se enfrentaron a la patronal, a los dirigentes sindicales tradicionales de la Confederación General del Trabajo (CGT) - orientada por el metalúrgico José Ignacio Rucci-y al gobierno militar encabezado por el Gral. Marcelo Levingston, quien en marzo de 1971 fue sucedido por el Gral. Alejandro A. Lanusse (James; Doyon). SiTraC y SiTraM protagonizarían uno de los procesos de radicalización obrera resultantes del Cordobazo -la insurrección obrero-estudiantil de mayo de 1969- y luego del Viborazo -la segunda insurrección cordobesa, desatada el 15 de marzo de 1971-(Brennan; Brennan y Gordillo; Mignon). 
La historia del SiTraC y de parte de la llamada "nueva izquierda argentina" puede ser recuperada a través de las fichas del "Archivo del SiTraC", actualmente disponible en forma digital en http://www.archivositrac.org. ar/. Confirmando las débiles políticas archivísticas argentinas (Tarcus, "Los archivos"; Caimari), el sitio no menciona a Fiorito como la responsable del resguardo, el ordenamiento y la reproducción de los documentos conservados en el fondo de archivo.

Siguiendo a De Certeau: "Todo comienza con el gesto de poner aparte, de reunir, de convertir en documentos algunos objetos repartidos de otro modo. Esta nueva repartición cultural es el primer trabajo. En realidad consiste en producir los documentos por el hecho de recopiar, transcribir o fotografiar dichos objetos cambiando a la vez su lugar y su condición" (85-86). En diversos reportajes, Fiorito recuerda que continuó reuniendo materiales luego del 26 octubre de 1971, cuando los militares reprimieron con tanques y helicópteros a los obreros del SiTraC y encarcelaron a muchos de sus dirigentes. En uno de esos reportajes, aclara:

Todo el archivo se manejó - desde 1971 hasta que se microfilmó- en el soporte papel original. En soporte papel se clasificó (desde 1974 a 1976), y se hicieron los índices (desde 1976 hasta mediada la década de los 80). Íbamos sacando de su escondite los documentos originales, carpeta por carpeta, rotulábamos y hacíamos los índices; son 18.000 folios, y no contábamos con ninguna fotocopiadora ni otro medio de duplicación. Para hacer el trabajo tuvimos muchos años jtoda la dictadura! Éramos dos. Supongo - porque nunca se lo pregunté- que "N" llevaba a su casa cada carpeta que yo le daba y que trabajaría en el galpón de herramientas, en su casita del Camino Negro. Yo hice un acuerdo con mi jefe, y me quedaba fuera de hora -de 18 a 20 - en la oficina de un insospechable organismo internacional, tipeando los índices, con una gata en el regazo. ("Entrevista a Susana Fiorito" 287)

En 1983, recuperada la democracia, Fiorito se reencontró con los militantes clasistas y agregó nuevos materiales al Archivo. Aparentemente, en 1994 obtuvo un financiamiento del Arquivo Edgard Leuenroth de la Universidad de Campinas (Brasil) para microfilmar el fondo de archivo, y envió una copia al Instituto de Historia Social de Amsterdam y otra a la Universidad de Harvard. En la década siguiente, esos documentos microfilmados fueron digitalizados y grabados en tres CDs. Actualmente, el archivo físico es resguardado, bajo el cuidado de Fiorito, por la Fundación Pedro Milesi y la Biblioteca Popular de Bella Vista, un barrio de las afueras cordobesas. 


\section{MEMORIA OBRERA, MEMORIA INTELECTUAL}

La tarea de reunión, repartición y producción documental que realizó Fiorito nos recuerda a ese intelectual que, siguiendo a Rancière, "no simplemente sabe hablar [o escribir] mejor", sino que fue buscado "porque hay que representar frente a los burgueses [...] a los sujetos de un discurso colectivo que da sentido a la multiplicidad de sus agrupaciones y sus combates" (Rancière 21). La experiencia del SiTraC fue tan significativa para la nueva izquierda que otros intelectuales también buscaron conservar su memoria. No solo publicaron artículos y libros con su historia, sino que incluso iniciaron la construcción de nuevos fondos de archivo. Los intelectuales que editaban en Buenos Aires la revista marxista estructuralista Los Libros (1969-1976) dedicaron la entrega de agosto de 1971 a esa experiencia. Allí incluyeron el discutido "Programa del SiTraC-SiTraM" y una entrevista a uno de sus dirigentes, Gregorio Flores (1934-2011). Los intelectuales de otra revista porteña, en este caso ligada a la tendencia revolucionaria del peronismo, Cristianismo y Revolución (1967-1971), difundieron ese Programa junto a informes y panfletos obreros (Celentano, "Insurrección obrera"). Por su parte, la editorial porteña La Rosa Blindada publicó en 1973 el libro de Beba Balvé, Roberto Jacoby y Miguel Murmis, entre otros intelectuales, titulado Lucha de calles, lucha de clases, en el cual compilaron volantes y entrevistas a los clasistas.

Otro intelectual que se ocupó de la memoria clasista fue Ricardo Piglia (1941-2017). Sobre las entrevistas, aún inéditas, que les realizó a los obreros cordobeses, reflexiona en uno de sus diarios:

Grabé las entrevistas y las historias de vida cuando pasé unos días allá y me conectaron con los obreros de FIAT. La pregunta es ¿cómo fue derrotada la comisión interna que dirigió las luchas? O mejor: ¿por qué fue derrotada? En ese punto los testimonios funcionan como declaración ante un tribunal y la pregunta tiene la forma de un interrogatorio. Así la tensión tiene que estar dada por la circulación sin fin de los argumentos. Se trata de un caso, de un exemplum en el sentido clásico, lo que me afecta es que estamos haciendo siempre registros de la derrota. No hay otra cosa que derrota en el horizonte, interesante desde el punto de vista épico pero tristísimo desde el punto de vista político. (Piglia 383)

Por su parte, José Aricó, el líder cordobés del grupo gramsciano Pasado y Presente (PyP), en 1972 seleccionó y ordenó documentos para armar un "dossier". 
Allí se reunieron notas sobre los dos sindicatos de empresa y las desgrabaciones de tres entrevistas a dirigentes de SiTraC y SiTraM, realizadas en 1971 por Jorge Feldman y Jorge Tula. Pero quedó inédito hasta 2009 (Schmucler et al.). Ese mismo año 1972 se abría un escenario electoral y el grupo PyP decidía vincularse a las organizaciones armadas peronistas. Entonces a Aricó ya no le interesaba publicar documentos sobre una experiencia que no solo se autonomizó del control de la burocracia sindical peronista, sino que además cuestionó el poder estatal y la salida electoral que impulsaban las diversas tendencias del peronismo. ${ }^{1}$

Con el objetivo de reconstruir la historia clasista $-y$ marcar sus diferencias con $\mathrm{PyP}-$, en 1984 Fiorito volvió a entrevistar a dirigentes del SiTraC. ${ }^{2}$ Las desgrabaciones de estas nuevas entrevistas, la memoria redactada ese año por Gregorio Flores, las cuatro "Entrevistas de PyP" y la serie fotográfica fueron incorporadas al subarchivo 12, rotulado como "Materiales para reconstruir la historia (incluye algunas fotografías y la desgrabación de entrevistas de 1971 y de 1984)". Fiorito y el grupo de obreros entrevistados ordenaron los materiales del subarchivo y les agregaron numerosos comentarios en los márgenes. A partir de esos comentarios podemos explicitar las tesis históricas que se asumió en la organización del Archivo. Por un lado, la capacidad política obrera en la fábrica y la fuerza social de los sindicatos clasistas serían rasgos determinantes y destacables en el despliegue de las insurrecciones cordobesas. Por el otro, el desafío clasista al poder de la CGT fue acompañado por el desarrollo de organizaciones como Vanguardia Comunista, el Partido Comunista Revolucionario y el Peronismo de Base, entre otras tendencias de la nueva izquierda.

Elfondodearchivotiene unainteresanteidentidad:contiene documentación generada por un colectivo sindical, pero también un ordenamiento y más documentación generada por una persona, Susana Fiorito. Sobre esa condición

1 Más precisamente, a mediados de 1972, el grupo apoyó a Montoneros, Fuerzas Armadas Revolucionarias y Fuerzas Armadas Peronistas y en 1973 convocó a votar a la fórmula peronista encabezada por Héctor Cámpora y Vicente Solano Lima. Este reposicionamiento tuvo repercusiones en Los Libros. A fines de 1972, su director Héctor Schmucler -también integrante del grupo PyP y que apoyaba la peronización- fue desplazado por Ricardo Piglia, Carlos Altamirano y Beatriz Sarlo, tres miembros del comité editor que se alineaban con partidos maoístas opuestos a la peronización de los intelectuales.

2 A mediados de los años ochenta, cuando se terminó de fotografiar el conjunto del Archivo del SiTraC, se agregó un "subarchivo 0" que resume en breves líneas el contenido de cada uno de los 20 subarchivos. En el resumen correspondiente al "subarchivo 12" se informa: "las entrevistas de Pasado y Presente -que registran la tendencia política de cada delegado encuestado- son indicadores del nivel de conciencia política de los mismos y de su opinión sobre la politización de las bases. También demuestran claramente las diferencias -en cuanto a maduración ideológica y a relación de los dirigentes con los operarios- entre SiTraC y SiTraM". 
anfibia traigamos algunos de los comentarios editoriales que fueron agregados en 1984 en marginalia a la desgrabación de una entrevista. Fiorito desgraba a máquina el relato del obrero clasista Carlos Masera y en el margen incorpora, también a máquina, un pedido para Masera: “Además, por favor, marcar todo lo que no esté claro, o lo que esté equivocado, así lo podemos corregir cuando yo vuelva por allá". Y agrega en letra manuscrita: "Donde dice 'S.F.' es para que averigüe yo". En el mismo documento, el obrero "Pedro" escribe a mano información sobre la toma de la fábrica de enero de 1971 y anota una frase marxista que probablemente provenga de su contacto con los intelectuales: "comprender es superar". Estas y otras operaciones sobre el archivo son las huellas de una intervención personal de Fiorito en la que su condición de entrevistadora se anuda con la marginalia para afirmar y glosar la emergencia del discurso colectivo de los trabajadores y comprobar la elevación de su conciencia política. Ver imagen 1 (Subarchivo 12, ficha 1)

Imagen 1: Recuerdos de Masera mecanografiados por Fiorito (15/07/1984). Notas manuscritas de Fiorito, Masera y "Pedro".

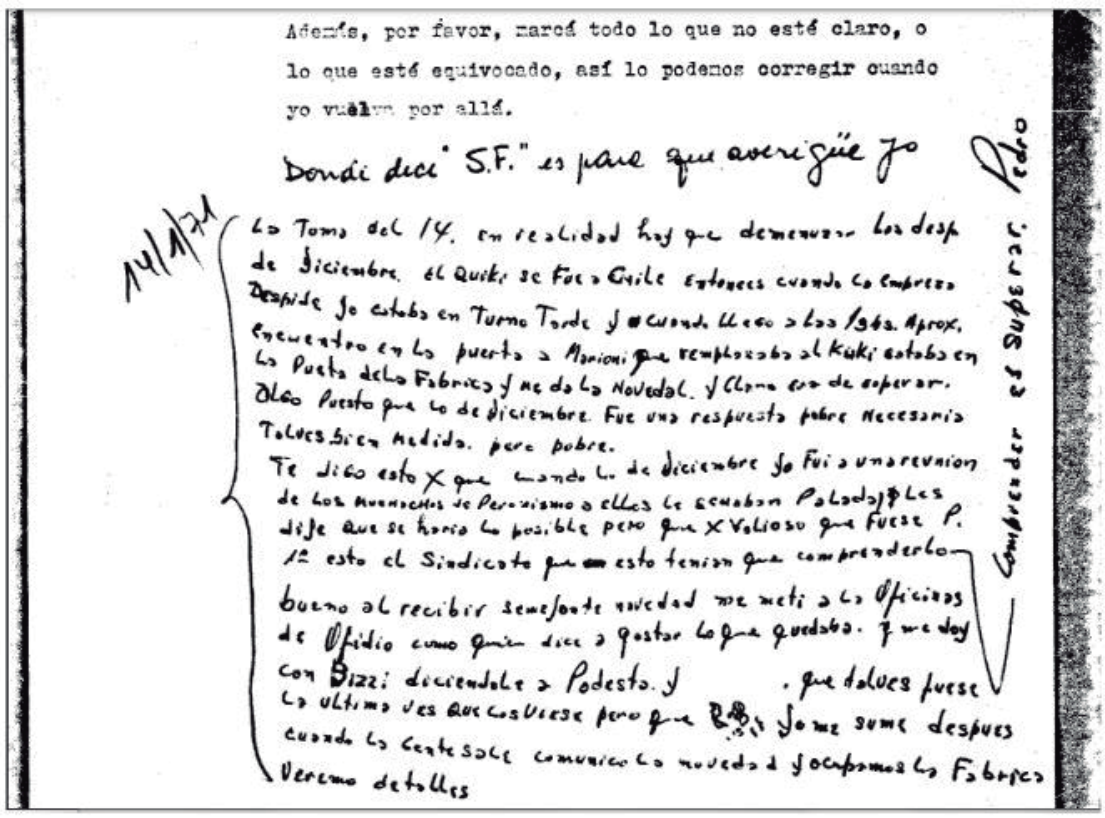

Fuente: Archivo SiTraC, subarchivo 12, ficha 1. 
En primer lugar, nos interesa precisar las opciones político-archivísticas realizadas por Fiorito al construir un acervo documental que no debía volverse una multitud amorfa ni una linealidad sin rupturas. Es que, lejos de ello, su constructora buscó tanto registrar la potencia del clasismo y de la nueva izquierda como, a partir de la edición y de la digitalización, impulsar la reactivación de ese pensamiento político obrero. En segundo lugar, si el ordenamiento y la estructura de los subarchivos y fichas nos permiten registrar lo que Rancière llamó el "archivo del sueño obrero", la marginalia insertada por los obreros y Fiorito en los materiales del archivo podría introducirnos en los dilemas de los intelectuales y con ellos en los del clasismo y de la nueva izquierda en general. El abordaje desde esas dos dimensiones del Archivo SiTraC ilumina nuevos aspectos de la "isla" o el "archipiélago" que modeló la intervención de una integrante de la nueva izquierda intelectual, actualmente a cargo de una importante biblioteca popular cordobesa (Celentano, "Un análisis").

\section{ARCHIVO: ¿INDIVIDUAL O COLECTIVO?}

Mucho se ha reflexionado sobre la noción de lo personal así como sobre las tensiones entre el "individuo" y el "colectivo". Retomemos aquí la propuesta de Saul Karsz de neutralizar la "supremacía del individuo" a partir de reconocerlo como no indiviso y no constituido por una sola pieza, y de estudiarlo al interior de la construcción socio-histórica que permite reconocerlo y reconocerse como sujeto.

Las autonomías relativas que guardan los individuos, en tanto sujetos, respecto del colectivo al que pertenecen pueden iluminar las operaciones sobre el fondo de archivo que analizamos. El orden, el recorte y la reproducción de los subarchivos y fichas así como las entrevistas y la marginalia visibilizan la autonomía de Fiorito. Pero esta autonomía estuvo sobredeterminada por las prácticas de colectivos políticos y obreros clasistas: específicamente, las prácticas de la Secretaría de prensa del SiTraC y las de lo que desde los años sesenta se identificaba con la nueva izquierda (Tortti). Se trató de decisiones individuales y colectivas situadas en dos coyunturas: la de los primeros años setenta con la irrupción del acontecimiento clasista y la de fines de los años ochenta cuando se buscaron recuperar los efectos de aquel acontecimiento mediante la constitución del Archivo y la publicación de una historia del SiTraC. A partir de esas definiciones precisemos el problema en el campo historiográfico contemporáneo.

Siguiendo a los historiadores franceses Philippe Artières y Dominique Kalifa, en los últimos treinta años la relación entre el historiador y los archivos 
personales se vio estrechada por una revalorización historiográfica de las fuentes autobiográficas, al tiempo que emergió con fuerza la relación entre los "testimonios" y el mundo de la "verdad". Esa revalorización reforzó la atención a la escritura en la construcción de los objetos históricos, pero también trajo cierta incertidumbre. Se abre allí una tensión aún irresuelta. Para algunos historiadores, los archivos personales permiten rescatar las discontinuidades de una vida. En cambio, para otros, ese tipo de archivos son un acceso a la reorganización y la reescritura de los documentos conservados, y ofrecerían también un significativo cruce con otro tipo de documentos.

Artières y Kalifa señalan tres momentos de la evolución de los estudios sobre los archivos. El primer momento se registra luego del Mayo francés de 1968 y su revalorización de los "condenados de la tierra" se centra en las historias de los obreros y los marginales, o esa "crónica de la memoria obrera" que promovía Michael Foucault. El segundo momento se preocupa por las condiciones de producción de los discursos reunidos en los archivos, es decir, analiza las prácticas sociales de las que provienen los archivos. El tercer momento está marcado por la prioridad de lo "infraordinario", en este caso el foco pasaría de la búsqueda de lo extraordinario a la identificación de lo cotidiano.

Salir del "ídolo individual" sin oponerlo al "ídolo social" centrado en la estructura de lo social implica un problema difícil de resolver; problema emergente con el retroceso de los estudios centrados en la totalidad social en beneficio de la singularidad, desplazamiento que abrió paso a la historia cultural. Para Artières y Kalifa, la atención de los historiadores a la "desviación" o al "margen" respecto de la regularidad, y la valorización de la multiplicidad de las experiencias por sobre la racionalidad de las limitaciones, acarrean el riesgo de fragmentar ilimitadamente el objeto. Al punto que la sociedad no existiría más que en su estallido y en el encabestramiento de las prácticas, representaciones y experiencias, y se correría el riesgo de reducir el análisis histórico a la impotencia explicativa. Artières y Kalifa proponen una historiografía -que podemos alinear con la de Rancière y la de Karsz- que parte del reconocimiento de que la conciencia de sí transita por las marcas sociales de la memoria y de la representación. Conciben que la frontera entre lo íntimo y lo público se difumina en una suerte de "yo colectivo", y la desviación y la singularidad toman sentido cuando se las relaciona con un sistema de limitaciones y de normas. Lo "real" emerge en esa articulación solamente si se reconocen los múltiples recaudos para esta empresa y si se encuentran en estos archivos los medios para convocar a los actores sociales junto a las estructuras que los contienen, para ligar y leer sociedades y representaciones. Este breve y conciso recorrido conceptual no impide reconocer que, como señalan Nazar y 
Pak Linares, la archivística en tanto "formación discursiva” sufre los problemas metodológicos del (des)orden y la selección de fuentes, similares a los de las ciencias sociales.

\section{FIORITO: DE LA SECRETARÍA DE PRENSA DEL SINDICALISMO CLASISTA AL ARCHIVO DEL SITRAC}

Con la formación del movimiento obrero argentino y su acción directa, a fines del siglo XIX algunos militantes, sea anarquistas o socialistas, comenzaron a reunir colecciones y archivos que, alojados en bibliotecas, mutuales y sindicatos, conservaban la memoria del movimiento (Tarcus, Marx; Fernández Cordero; Domínguez Rubio). Desde fines de los años veinte, los comunistas se sumaron a la tarea archivística para, en este caso, asociar a una representación clasista de la historia las memorias de los obreros y obreras (Camarero; Petra). Anarquistas, socialistas y comunistas, además, promovieron el encuentro de los obreros con los agrupamientos intelectuales, o directamente la formación de intelectuales obreros. Fiorito se reivindicó como intelectual marxista e insistió en que sus libros y folletos así como los documentos del Archivo debían tener como objetivo la memoria y reivindicación de la acción directa obrera iniciada a fines de siglo XIX -y asociada a la práctica clasista desde los sesenta-.

A mediados de los años sesenta, cuando se disgregó el grupo contornista en el que se habían formado Fiorito, Ismael Viñas y otros, ella trabó relación con el escritor Andrés Rivera, recientemente expulsado del Partido Comunista. En esos años, el escritor se ligaba a los maoístas de Vanguardia Comunista (VC), viajaba a China y colaboraba con No Transar, el periódico de ese partido. ${ }^{3}$ Sería VC la organización que, a fines de 1969, le propusiera a Fiorito instalarse en Córdoba para colaborar con la Secretaría de Prensa del SiTraC, donde esos maoístas intentaban consolidar su presencia. Las relaciones de VC con los intelectuales son una referencia clave en los tres tomos de la reformulación ficcionalizada de su biografía que realiza Piglia en Los diarios de Emilio Renzi. En la "Serie X" de esos diarios, Piglia describe las reuniones que había tenido en su departamento porteño con los obreros, además lista sus participaciones

3 Recordemos que hasta mediados de los años 80 la narrativa de Andrés Rivera busca inscribirse en esa memoria obrera, pues otorga un espacio privilegiado a la representación de la vida cotidiana y la lucha de los obreros y obreras. 
en las publicaciones maoístas Cuadernos Rojos, Desacuerdo y No Transar. ${ }^{4} \mathrm{Si}$ bien Fiorito llegó al SiTraC por VC, pronto consolidó su lazo con el Sindicato y mantuvo importantes divergencias con los maoístas. Sus simpatías estuvieron con la tendencia marxista El Obrero, hasta que esta pasó a la lucha armada en 1973 con el nombre de Organización Comunista Poder Obrero (OCPO).

A fines de 1971, cuando los militares intervinieron los sindicatos clasistas, Fiorito concentró su actividad política en la solidaridad con los obreros presos del SiTraC, con los despedidos y con los más de 400 trabajadores que figuraban en las listas negras de las patronales. Fue entonces que Fiorito comenzó a custodiar lo que sería el Archivo de SiTraC, al que sumó materiales que informaban sobre el desarrollo de los grupos clasistas en las fábricas Perdriel, Perkins, Grandes Motores Diesel, Thompson Ranco, ILASA y algunas otras. En 1972 la tendencia clasista liderada por el militante maoísta René Salamanca-e integrada por diversas corrientes de la nueva izquierda- ganó la dirección del poderoso Sindicato de Mecánicos y Afines del Transporte Automotor (SMATA), seccional Córdoba. Este sindicato se enfrentó a las patronales y a la dirección de la CGT, hasta que en 1974 fue intervenido por el gobierno peronista. Como mencionamos, ese año Fiorito utilizó el Archivo de SiTraC para escribir una de las primeras historias de la tendencia clasista. Al texto que resume los cordobazos lo acompañan fotografías de la lucha de calles y de enfermeras en una olla popular; afiches que exigen la libertad de los obreros clasistas presos y otros de convocatorias de las Ligas Agrarias; y las fotos del líder cordobés de Luz y Fuerza Agustín Tosco, del gráfico que ocupaba la secretaría de la CGT de los Argentinos, Raimundo Ongaro, y del dirigente del Sindicato de Prensa y militante de VC Emilio Jaúregui, asesinado por la policía en 1969. La última página del fascículo publicado por el CEAL reproduce un fragmento de un artículo informativo que había aparecido en el diario La Opinión- del diálogo que, en el marco del Gran Acuerdo Nacional (GAN), habían tenido el 9 de septiembre de 1972 el presidente de facto Lanusse, el secretario general de la CGT José Ignacio Rucci y el representante de los empresarios nacionales José Ber Gelbard. El diálogo culmina con este intercambio irónicamente amistoso:

4 Piglia insiste en que esa prensa maoísta se valía de un estilo lingüístico remanido, simplificador y despolitizante (Piglia 209). Pero ello no le impedía participar en las actividades universitarias cordobesas ligadas abiertamente a VC y a los obreros de SiTraC-SiTraM. Por los mismos diarios sabemos que en 1970 Piglia participó de un conocido encuentro nacional de intelectuales, organizado en Córdoba, en el que promovió, a distancia de los integrantes de Pasado y Presente, una literatura hecha de "manifiestos, relatos fotocopiados, historias de vida" (Piglia 226). 
Lanusse: [esto] es un motivo más de compromiso y satisfacción. Simplemente, les quedo muy agradecido.

Rucci: La coincidencia llega también con los empresarios al plan de lucha (risas)

Lanusse: Avíseme... yo me paso del lado de ustedes.

Gelbard: El próximo plan de lucha lo hacemos todos. (Duval, "Argentina" 320).

En su síntesis del clasismo, Fiorito utiliza ese diálogo para mostrar la fuerza del gobierno que impulsaba el GAN y el rol decisivo que tuvo la subordinación de la CGT -que ese año había clausurado sus planes de lucha-. Anticipemos que en las entrevistas que realizó en 1984 Fiorito convirtió el citado artículo de $\mathrm{La}$ Opinión en un documento que le permitía orientar y profundizar el diálogo que se incorporó al subarchivo "Materiales para reconstruir la historia".

Producto de esa labor de Fiorito y su compañero "N", el Archivo del SiTraC quedó organizado en 20 subarchivos, titulados temáticamente. En conjunto, el Archivo contiene 224 fichas con aproximadamente 70 fotogramas cada una. Se pueden distinguir tres grupos entre los subarchivos. Los primeros once reúnen información sobre los conflictos en las fábricas cordobesas (esto es, las confrontaciones que permitieron a las bases la destitución de Jorge Lozano y los otros dirigentes burocráticos del SiTraC y SiTraM), sobre la emergencia de las concepciones clasistas de los nuevos dirigentes de ese sindicato y sobre sus intervenciones frente a la patronal de FIAT, a los dirigentes de la CGT y a las Fuerzas Armadas. A partir del subarchivo 12, titulado "Materiales para reconstruir la historia", los subarchivos incorporan información sobre el contexto político, por ello contienen recortes de prensa periódica masiva, de prensa de organizaciones no partidarias así como informes de organismos estatales sobre el mundo laboral. El tercer grupo lo componen los tres últimos subarchivos que reúnen más de un tercio de la totalidad de las fichas (81 sobre un total de 224). Estos subarchivos incorporan la prensa de las organizaciones políticas de la nueva izquierda, especialmente de VC y del Partido Comunista Revolucionario (PCR); y esa prensa ocupa más de 50 fichas. El volumen de la documentación agrupada en los subarchivos de lo que distinguimos como un tercer grupo obedece a la decisiva relación que esos dos partidos maoístas mantenían con la Secretaría de prensa del SiTraC.

Otras organizaciones de la nueva izquierda, como el Peronismo de Base (PB) y, en menor medida, el Partido Revolucionario de los Trabajadores-Ejército Revolucionario del Pueblo (PRT-ERP), les diputaron a los maoístas la influencia en las masas obreras de la FIAT cordobesa (Carnovale; Ortiz; Laufer). Fiorito 
dejó marcadas sus diferencias con esas organizaciones armadas en el subarchivo dedicado a la reconstrucción de la historia del clasismo, al que le dedicamos el próximo apartado.

\section{LOS MATERIALES PARA RECONSTRUIR UNA HISTORIA EN DISPUTA}

El subarchivo 12 fue armado en 1984 y contiene cuatro fichas. Las dos primeras fueron elaboradas inmediatamente después de la recuperación de la democracia. El presidente de la nación, Raúl Alfonsín, pertenecía a la corriente progresista de la Unión Cívica Radical (el tradicional partido liberal argentino) y levantaba entonces la "democracia sindical" como bandera de su gobierno. El grupo reunido en torno de Fiorito y Rivera no encontró en la política nacional ninguna democratización del mundo obrero y apostó a recuperar la memoria de la experiencia que más cerca estuvo de esa democracia, la organización clasista de los sindicatos. La normalización democrática se realizaba en una sociedad que tenía a su izquierda marxista diezmada por la represión dictatorial, ya que la mayoría de los dirigentes y delegados de base clasistas había sido blanco privilegiado de apresamientos, secuestros, torturas y desapariciones durante la dictadura cívico militar instaurada el 24 de marzo de 1976, y debieron pasar varios años para que la recuperación del Archivo del SiTraC produjera efectos en la memoria obrera.

Las desgrabaciones de las entrevistas realizadas en julio y noviembre de 1984 por Susana Fiorito a Carlos Masera (ex Secretario General de SiTraC), Rafael Clavero (ex Secretario de Prensa), Santos Torres (ex Secretario de Organización) y José Ponce (activista) aparecen en las primeras dos fichas del subarchivo. En ellas se consigna la intervención de Fiorito como entrevistadora y como generadora de numerosas anotaciones al margen. Fiorito estaba encargada de recabar la información que contenía el Archivo sobre la organización política y gremial de 1970-1971 y para ello debió revisar sobre todo los boletines, comunicados, volantes y recortes de prensa. El subarchivo también contiene documentos rotulados como "Memorias de Gregorio Flores", fragmentos inéditos de las Lecciones de batalla que ese obrero clasista publicaría en 2016. Allí anuncia una "solicitud al historiador James Brennan (donante), por faltante" y se conservan las "Entrevistas de Pasado y Presente a dirigentes y activistas", realizadas en 1971, y las fotografías del entierro del obrero Adolfo Cepeda, asesinado en marzo de ese año.

$\mathrm{Al}$ interior del subarchivo, Fiorito construye dos series de documentos: en primer lugar, sus entrevistas de 1984 y las "Memorias" de Flores, que se apoyan 
en los documentos de los otros subarchivos y, en segundo lugar, las entrevistas realizadas por el grupo Pasado y Presente, en las fichas 3 y 4 . Estas últimas entrevistas ofrecen balances divergentes a los publicados en 1988 por Fiorito y su grupo -con la firma de Natalia Duval- en el libro Los sindicatos clasistas: SiTraC (1970-1971).

Por su parte, las nuevas entrevistas que Fiorito realizó a Masera, Clavero, Torres y Ponce, así como las "Memorias" de Flores, nos permiten registrar, por un lado, las convicciones de Fiorito en tanto generadora, organizadora y usuaria del archivo y, por el otro, el sentido político-ideológico que asumieron los entrevistados cuando en 1984 recuperaron su experiencia de los años 19701971. Como ya dijimos, el principal interés del grupo residió en asociar el relato de la experiencia obrera en la fábrica con el proceso de politización clasista definido. Para ello destacaron la rebelión obrera espontánea contra los dirigentes en las asambleas, y las tomas de fábricas contra Lozano y la dirección del SiTraC -quienes apoyaban el sistema de explotación de FIAT. Las asambleas y las tomas de 1970 habrían sido centrales en la impugnación del modelo sindical peronista y la recuperación de la acción directa obrera.

Al igual que otros documentos y fichas, las entrevistas ligan el acontecimiento de 1970 a la derrota de los obreros de FIAT en 1965, quienes fueron aislados por la UOM y la CGT cordobesa. En uno de los fotogramas de la "ficha 1" encontramos las anotaciones de un obrero que rectifica una información. Escribe: "No, lo que sigue corresponde al periodo Carrasco", subraya el pasaje de la entrevista en el que se denuncia la negativa de la CGT a convocar a un plan de lucha y anota al margen su interpretación del rol de un tal Luis Juárez en 1965:

Lo que ocurre con Luis Juárez es que después del relato de Flores en el periodo de Lozano la FIAT y UOM buscan consolidar o al menos hacer potable un sindicato pro UOM y Juárez que fue despedido junto al resto viaja a Buenos Aires por cuenta propia y Vandor le arregla la reincorporación al sindicato para ayudarles. (Subarchivo 12 ficha 1$)$.

La marginalia del obrero explica cómo pudo mantenerse Lozano en el SiTraC después de la derrota de 1965: el arreglo de algunas reincorporaciones le permitió mantener su poder. Por su parte, Fiorito extrae numerosos datos tanto del artículo de José Aricó, aparecido en el último número de la revista Pasado y Presente (1965), como de No transar. El objetivo de Fiorito emerge 
en la marginalia y en otros subarchivos: ella se propone mostrar que la táctica del sindicalismo peronista fue la principal responsable de la derrota de los planes de lucha porque no los implementó de modo consecuente o se negó a una orientación clasista, antes y después de la experiencia de SiTraC-SiTraM. Ver imagen 2, (Subarchivo 12, ficha 1).

Imagen 2: Recuerdos de Masera mecanografiados por Fiorito (15/07/1984) con notas manuscritas de Masera.

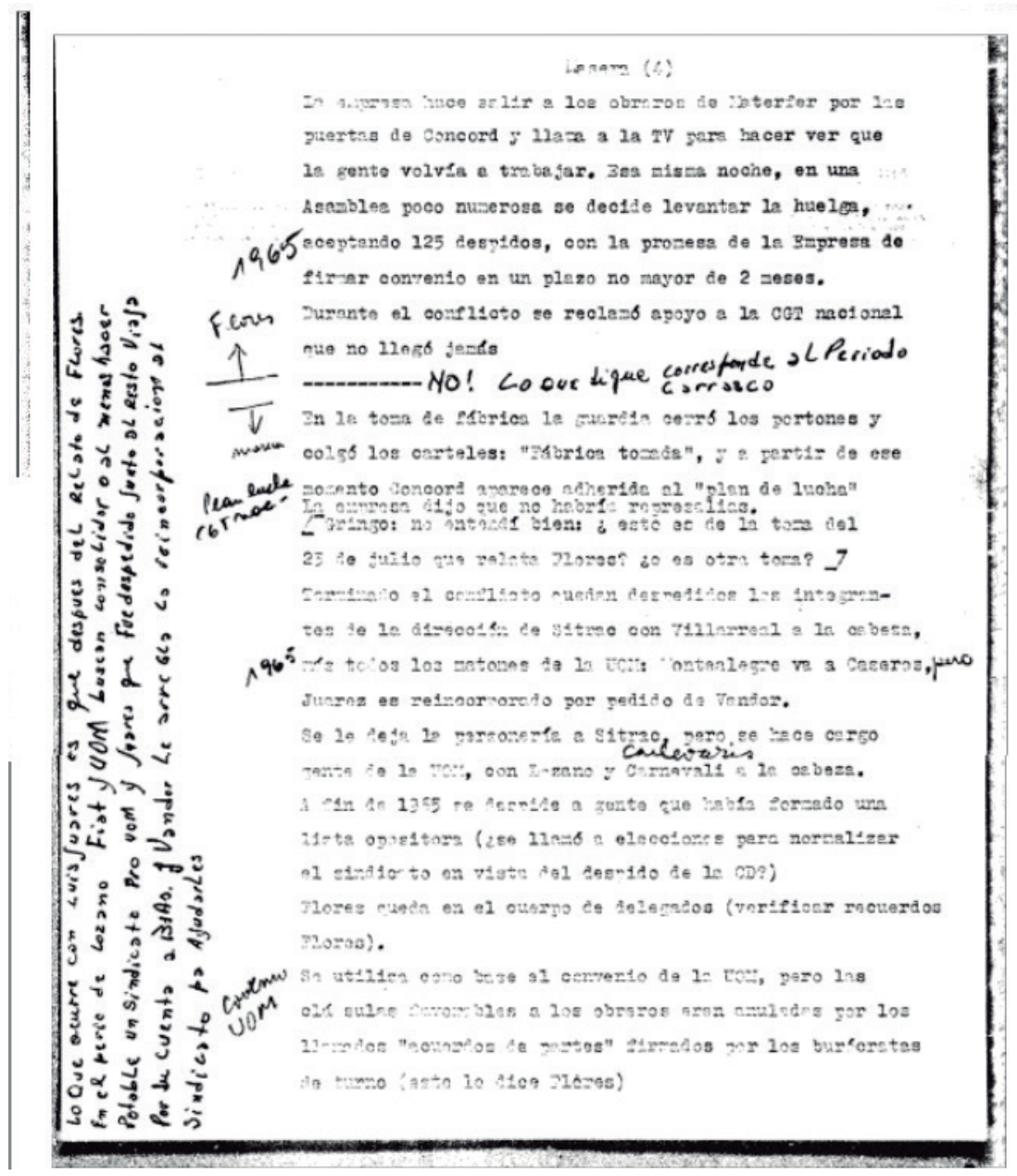

Fuente: Archivo SiTraC, subarchivo 12, ficha 1. 
Las anotaciones y rectificaciones que acompañan las entrevistas a los obreros y las intervenciones de Fiorito buscan resaltar la potencia de los nuevos métodos de lucha marcados por la acción directa, el funcionamiento de la democracia sindical y las relaciones de los obreros con el movimiento estudiantil cordobés. Estas novedosas formas de acción obrera constituirían el elemento decisivo que desembocaría en las insurrecciones llamadas "Ferreyrazo" y "Viborazo", en las cuales las organizaciones revolucionarias habrían desempeñado un papel menor, pues se subordinaron a las iniciativas de las masas obreras. Según la reconstrucción de Fiorito y los entrevistados, el punto decisivo de la política clasista aparece en el famoso programa del SiTraC-SiTraM que define su línea "antipatronal, antiburocrática y atimperialista" y culmina con la consigna: "Ni golpe, ni elección: Revolución!".5

Las entrevistas que realizó Fiorito en 1984 y algunos documentos de los primeros subarchivos fueron la base de la crónica histórica de Los sindicatos clasistas: SiTraC (1970-1971), libro firmado por Natalia Duval y aparecido en 1988. Al igual que las marcas en el Archivo y el fascículo editado por el CEAL en 1974, el libro enfatiza la potencia de la combatividad obrera, de las asambleas con tomas de fábricas, de la alianza con los estudiantes, de la ocupación obrera de los barrios y de las insurrecciones populares. La potencia de la acción directa obrera y popular aparece explícitamente diferenciada de la acción de las organizaciones armadas marxistas o peronistas. ${ }^{6}$ Esas diferencias y tensiones entre el trabajo del grupo de Fiorito y los grupos intelectuales y políticos que optaban por la vía armada o por la peronización también se advierte en el subarchivo que analizamos antes.

En documentos del Archivo que datan de 1971, Fiorito, los obreros entrevistados, y el abogado Alfredo Curutchet, sostienen que el programa del SiTraC-SiTraM resume las posiciones comunes elaboradas por la Comisión Directiva. El programa habría sido discutido entre los delegados y sus bases, y la asamblea habría acordado llevarlo como propuesta al Plenario nacional de gremios combativos, realizado en Córdoba el 21 y 22 de mayo de 1971. Por el contrario, el relato que aparece en el "dossier no publicado" de PyP, elaborado en 1972, sostiene que el Programa fue resultado de un "aparateo" del PCR: "El conocido Programa de S-S [SiTraC-SiTraM] fue elaborado en 48 horas. Fue, efectivamente, aprobado por los cuerpos de delegados y por una asamblea de Concord, pero sin discusión política ni en las bases, ni siquiera en el activo. El centro de atención en esos días estaba fijado en las tratativas con la empresa y fue aprobado por la confianza depositada en los dirigentes. Más tarde fue dejado de lado, e incluso repudiado por los delegados, que en su gran mayoría no lo entendían. Se lo veía como lo que era, el programa de uno de los partidos que actuaban en S-S que no daba cuenta de la experiencia de los obreros de Fiat", (Schmucler et al. 56).

6 Entre los 26 documentos reproducidos en Los sindicatos clasistas se encuentran dos "Comunicados de prensa del SiTraC", en los que esos sindicatos y su abogado Curutchet niegan supuestos vínculos con el secuestro del gerente de FIAT Oberdan Sallustro, quien en realidad había sido secuestrado por el ERP (Duval, Los sindicatos). 
Volviendo a las entrevistas de 1984, Fiorito refuerza la importancia de las asambleas masivas seguidas de la toma de fábrica a partir de preguntas sobre los conflictos fabriles en IKA-Renault y la matricería Perdriel, en la cual la "Agrupación 1 de Mayo", liderada por el PCR, había dirigido la protesta. Como entrevistadora y autora de marginalias, Fiorito agrega que los métodos de lucha en ambas automotrices sirvieron como ejemplo para la radicalización obrera en FIAT Concord. La ficha 1 registra la trama entre el pedido de Fiorito "tratar de recordar que", insertado a mano en el texto mecanografiado, y el texto manuscrito de un obrero, quien -con una ortografía deficiente- denuncia las maniobras del sindicalista burocrático Lozano: "El 24 hay movimientos por distintos lugares de la planta Lozano intenta ponerse al frente diciendo que si los obreros quieren se va a luchar por +". Abajo a la izquierda Fiorito interpreta y agrega: "24/3 diputa con Lozano x poder real". El obrero precisa a mano la habilidad que el dirigente del SMATA Elpidio Torres tenía para manipular las tomas de fábrica:

Preciado que así se llama el que me aviso era de la interna de reclamos de (Esmata) [sic] durante algún periodo de Torres en IKA que como allí se abía [sic] tomado algunas medidas de ese tipo tenia [sic] alguna experiencia.- De la segunda toma de FIAT si por lo ya conocido pero Elpidio no quería aflojar y como en Kaiser ocurrió lo de los desalojos pensamos que Podesta quería repetir la istoria [sic]". (Subarchivo 12 ficha 1). Ver imagen 3. 
Imagen 3: Recuerdos de Masera mecanografiados por Fiorito (15/07/1984) con notas manuscritas de Masera.

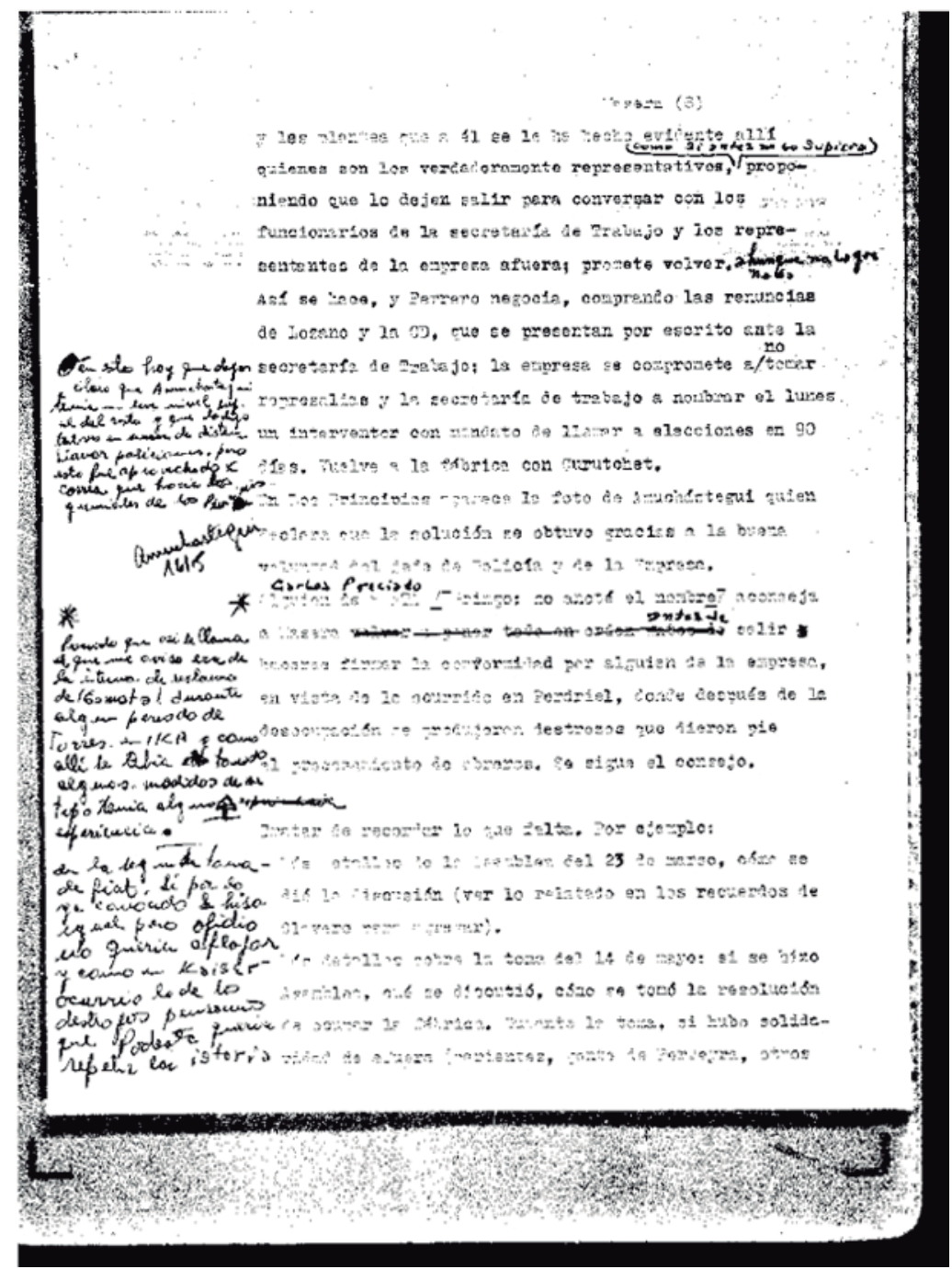

Fuente: Archivo SiTraC, subarchivo 12, ficha 1.

Como ya apuntamos, los delegados suman reflexiones y muchas de ellas testimonian el desafío afectivo con el que se involucraron en el trabajo colectivo de archivo: uno de los entrevistados anota los nombres de otros delegados y no se priva 
de agregar en letra manuscrita "me acordé mierda!". En la misma entrevista, Fiorito consigna datos de No Transar nro. 93 para recordar que debe interrogar a los obreros sobre la composición de la primera "comisión provisoria" y el rol desempeñado por Flores. En el margen dibuja una espiral que enlaza "colaboradora-provisoriaefectos": "colaboradora" era la comisión directiva "burocrática" del SiTraC, encabezada por Lozano; la "provisoria" refiere a la primera comisión elegida por las bases; y esta comisión desencadenó en abril de 1970 los "efectos" de ruptura con el modelo sindical tradicional (Subarchivo 12, ficha 1). Ver imagen 4.

Imagen 4: Recuerdos de Clavero mecanografiados por Fiorito (15/07/1984) con notas manuscritas de Clavero y Fiorito.

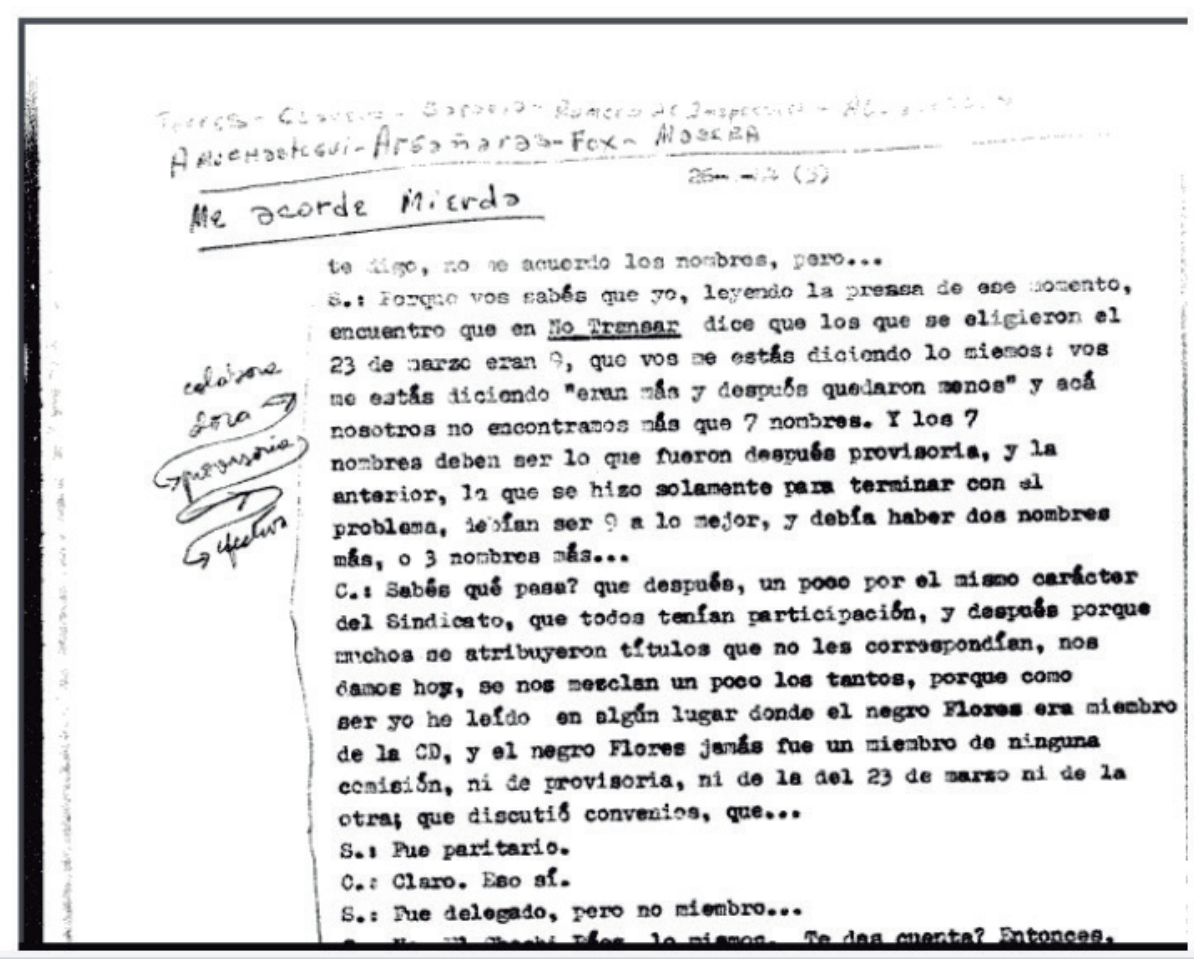

Fuente: Archivo SiTraC, subarchivo 12, ficha 1.

Las preguntas de Fiorito insisten en la importancia de otro problema sindical: un Convenio Colectivo de Trabajo más ventajoso para las bases obreras que el de la Unión Obrera Metalúrgica (UOM), o bien similar al vigente en otro sindicato, el SMATA (Subarchivo 12, ficha 2). 
En conclusión, la intervención de Fiorito busca recuperar en la inteligencia de los delegados obreros la confirmación de dos pasos clásicos del esquema marxista: el paso de la espontaneidad a la organización, y el de la lucha económica a la primera instancia de la lucha política, esto es la representación sindical que reclama un Convenio Colectivo de Trabajo que sea una mejor herramienta de disputa frente a la empresa y al Estado. En dicho esquema, el segundo paso, insinuado en las entrevistas y reforzado en la marginalia, consiste en la elevación de la conciencia obrera. Esta comenzaría cuando los sindicatos clasistas impugnan el control empresario de la producción fabril y concluiría con la proyección de esa impugnación al conjunto de la sociedad capitalista (Subarchivo 12, ficha 2).

En la reconstrucción oral de los obreros, la disputa por el nuevo Convenio aparece asociada a la protesta contra el aumento de los ritmos de trabajo, la sincronización de las máquinas y los premios por producción. Cuando Masera recuerda esa protesta como una "cuestión política", el Archivo vuelve a explicitar su doble condición personal y colectiva, esto es, de deber su existencia a la voluntad de preservar la memoria clasista que desplegó Fiorito, pero también de ser corregido y ampliado a partir de los documentos que se recogen en la tarea de preservación. Como entrevistadora, Fiorito ratifica la condición política que trae Masera y propone una deducción clásica del marxismo: la superexplotación en la producción facilitó la aparición de la conciencia. Otro entrevistado, Clavero, niega esa causalidad: la conciencia política habría provenido de la solidaridad. En la fábrica Concord los obreros, en su mayoría, apoyaron al sector Forja y ello los habría convencido de que también tenían que movilizarse por otros obreros en huelga, como los del calzado. Fiorito subraya las siguientes líneas de Clavero:

entonces esto está demostrando que había una conciencia política, no es cierto, medio, pero conciencia política al fin. Y eso se había logrado no porque el negro Flores planteara de que él... lo que a él lo guiaba era hacia el socialismo ni porque el peronista fuera a plantear otra cosa, ni porque el negro Masera hubiera expuesto... sino que era de que se había dado el problema de Forja, las 6 horas de Forja, y todo el mundo había hecho causa común con los compañeros de Forja. (Subarchivo 12, ficha 2).

Practicando un marxismo atento a los específicos procesos históricos, Fiorito traza una flecha hacia el párrafo subrayado y anota "la conciencia no les vino por formulaciones sino por hechos concretos (Forja)". E interviene de 
modo similar con los recuerdos de la discusión sobre el consumo de bebidas alcohólicas que había tenido Flores, anota "Choques por el vino en Forja, a raíz de eso discusión política". Los testimonios de Masera sobre las protestas por los ritmos y premios a la producción ofrecen otra confirmación de ese modo en que se alcanzaba la "conciencia obrera":

pienso, que quienes fueron los encargados de exponer en ese momento, de transformar lo puramente sindical a lo puramente político, tuvieron la suficiente capacidad dentro de sus limitaciones pero... muchas veces te traen un teórico y no encaja dentro de la conciencia de un obrero, y sin embargo un obrero muchas veces, con dos o tres palabras, dos o tres cosas que tenga en claro les hace que los compañeros las entiendan y las asuman como tales, que fue lo que sucedió. (Subarchivo 12, ficha 2).

Fiorito anota al margen: "de lo sindical a lo político" y "obrero como propagandista y portador de lo político". En la página siguiente continúan las notas: "se discute el sistema, no solo la FIAT... se agregó el aporte de las agrupaciones políticas [en la puerta de la empresa]... se incorpora gente a presenciar las discusiones políticas... politización de los + atrasados". El relato obrero sugiere la presencia de organizaciones de la nueva izquierda. Esa memoria no ha retenido nombres, pero le permite a Fiorito reconstruir una interacción, sobre todo con los estudiantes, que también habría jugado un papel importante en el proceso de elevación de la conciencia política obrera (Subarchivo 12, ficha 2). Ver imagen 5 . 
Imagen 5: Recuerdos de Clavero y Ponce mecanografiados (01/11/1984) y anotados por Fiorito.

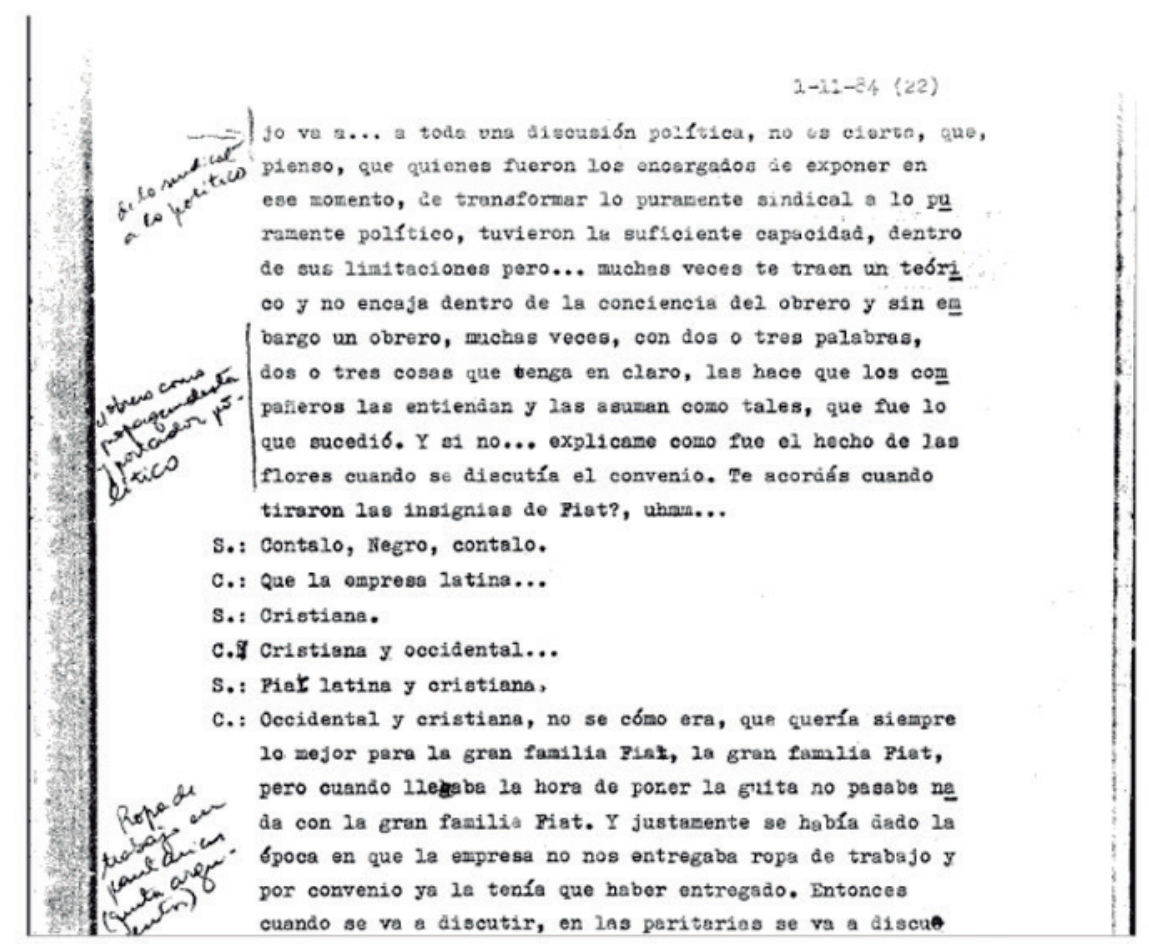

Fuente: Archivo SiTraC, Subarchivo 12, ficha 2.

Una clara marca personal que porta el Archivo se advierte en el tratamiento de los conflictos de 1971, sin embargo, esa marca solo se descubre cuando se conoce la obra de Fiorito. En la entrevista Fiorito resume el panorama político de 1971 y lo liga a la disputa sindical y al acuerdo de Perón con el general Lanusse, el presidente de facto. Uno de los entrevistados responsabiliza a los "burócratas sindicales" por la pérdida del nivel salarial y de los acuerdos con los militares, Fiorito lo interrumpe para retomar los argumentos que cerraban el fascículo que había publicado en 1974: "yo pienso que fue muy importante el acuerdo Perón-Lanusse y la apretada que Perón le hizo a Rucci y a la CGT y a todo eso para parar la cosa; eso fue importantísimo. Allí hubo un arreglo, es evidente, y además sale muy concreto de la información" (Subarchivo 12, ficha 2). 
Al reponer en 1984 los argumentos aparecidos en el fascículo de 1974, Fiorito hace que el Archivo proponga la derrota obrera de 1971 como una consecuencia de la desfavorable relación de fuerzas entre, por un lado, la intensa politización de la masa obrera ligada a la influencia de la nueva izquierda en la clase trabajadora y, por el otro, la alianza de la CGT, la FIAT y el gobierno militar. Esta tesis se opone abiertamente a las críticas al clasismo que formuló el grupo pasadopresentista en las "Entrevistas a los delegados y activistas" y también el PCR y el Peronismo de Base cordobés (PB), todas en 1971. Si bien ellas son conservadas en el Archivo, el subarchivo que analizamos encuentra la forma de deslegitimarlas a fin de consolidar las tesis políticas de Fiorito. ${ }^{7}$

\section{PASADO Y PRESENTE EN EL ARCHIVO DEL SITRAC}

Fiorito incorpora en las fichas 3 y 4 las entrevistas del grupo Pasado y Presente a dirigentes y delegados clasistas y a Alfredo Curutchet, abogado de esos sindicatos. En la "Entrevista. Dirigente del SiTraM" (subarchivo 12, ficha 3) el entrevistado rechaza lo que entiende como una excesiva politización del SiTraC. Esta es atribuida a las discusiones con el movimiento estudiantil y a la nociva influencia de ciertas "sectas" - con lo que probablemente se aluda a VC y el PCR. Según el dirigente, el contacto con los grupos izquierdistas, los teóricos y los estudiantes habría hecho que los delegados se distanciaran de las bases, asumieran una política sectaria y quedaran aislados frente a la patronal y la represión.

Estos análisis históricos no le permiten al entrevistado explicar los motivos por los que los dirigentes que mantendrían posiciones tan sectarias no perdieron el apoyo de sus bases aun durante la represión. Ni le permiten incorporar un rasgo que reconoce a lo largo de la entrevista: los obreros tenían simpatías tanto por los izquierdistas como por los estudiantes y por las organizaciones armadas. PyP agregó luego de la entrevista una extensa nota manuscrita -hoy muy borrosaque por la caligrafía no fue hecha por Fiorito ni Rivera y que aprueba y refuerza los argumentos del entrevistado.

Las citadas "Memorias" de Flores formulan una crítica al peronismo y a la CGT coincidente con la que Fiorito introduce en las entrevistas. En ambos documentos se señala que los obreros sabían perfectamente que sus delegados y dirigentes eran de izquierda y luchaban por el socialismo. Sobre esas luchas Flores no ofrece nuevas precisiones, más bien comparte el obrerismo asumido en 1983 por el Partido Obrero, del cual Flores entonces fue candidato presidencial. A diferencia de otros documentos del Archivo, las "Memorias" de Flores no tienen anotación al margen y Fiorito no las menciona en el libro que edita en 1988. 
En esa ficha 3, Fiorito incluyó las "Entrevistas. Delegados SITRAM", realizada por PyP. En ellas están subrayadas y destacadas las opiniones políticoideológicas de los dirigentes del SiTraM y de los delegados del Peronismo de Base, cuando los entrevistados se distancian del programa del SiTraC-SiTraM y especialmente cuando acusan a los clasistas de haber despreciado el hecho de que las bases eran peronistas. La nota final se inicia con el interrogante "por qué se desmovilizaron las bases", al que le sigue un resumen de las ideas vertidas por el delegado del PB. Quien realizó las anotaciones en el documento retoma esas ideas para objetar las repuestas de los delegados alineados con el PCR y VC.

La importancia del comentarista y su acuerdo con el planteo contrario al PCR y VC la encontramos en la "Entrevista a delegados del SiTraC" (subarchivo 12, ficha 3). Esta identifica a cada delegado con la organización de la nueva izquierda a la que pertenece: PCR, VC, PRT y PB. ${ }^{8}$ Los comentarios finales únicamente recuperan las respuestas subrayadas del delegado del PB, quien insiste en la inutilidad del Programa de SiTraCSiTraM y en la identidad peronista de los obreros. Es decir, si bien varios tramos de las respuestas de los delegados del PRT, VC y el PCR -agrupaciones con las que no se identificaban los entrevistadores- fueron subrayados, ellos no fueron retomados en los comentarios finales. Quien anotó el documento optó por agregar entrelíneas en manuscrito sus objeciones.

Desglosemos esas entrevistas. El delegado del PCR sostiene que lo novedoso del clasismo fue que incorporó a los obreros a la lucha política en lugar de que, como era costumbre, "otros sectores sociales" se encargaran "de hacer política para los obreros". Agrega: "lo nuevo es precisamente la inversa; que nosotros los obreros empezamos a buscar nuestro propio camino y nuestra propia política, con una ideología que corresponda a nuestros intereses". Tula y Feldman responden con una pregunta que insinúa una respuesta al PCR: "Dentro de las bases, el programa es totalmente aceptado?". La respuesta de "Varios delegados" fue: "Por completo". Los entrevistadores pasan entonces del Programa a la definición del sindicato y preguntan: "cuando dicen un sindicato clasista, que significa? a qué se refieren?". Para el delegado del PRT se trata del PB en Cristianismo y Revolución se orientan en el mismo sentido que las de los clasistas de VC y el PCR, es decir, allí no aparecen los reparos recogidos en las "Entrevistas de Pasado y Presente". Segundo, las numerosas intervenciones del delegado del PRT-ERP y de Curutchet, a quien se suele considerar ligado al PRT, recogidas por el Archivo muestran una simpatía y acuerdo con las líneas político-sindicales del PCR y de VC. 
de un sindicato "que responde al interés de clase. Clase obrera, única". El comentarista subraya esa repuesta y anota encima de las palabras del delegado perretista: "o sea que las bases [tachadura] aceptan el obrerismo". Tanto la pregunta como el comentario sugieren que para los entrevistadores de PyP el clasismo es conceptualmente débil y ciego a la cuestión peronista. La entrevista parece haber tenido esa forma de interrogatorio cuyo único horizonte es la derrota, derrota de la que, como citamos, Piglia en sus entrevistas intentaba una decidida distancia. Además, en la entrevista es claro que los intelectuales de PyP ya definieron sus críticas al clasismo y su apoyo al peronismo, otra decisión que Piglia cuestiona en sus diarios.

Volviendo al subarchivo 12, allí también se conserva la "Entrevista a los delegados de SiTraC" en la que el problema del Programa reaparece cuando Tula y Feldman les preguntan: "Cuando ustedes tienen que discutir su programa con alguna persona del sindicato que no lo entiende o que no lo acepte totalmente qué tipo de discusión se suscita?". El delegado del PCR responde "con respecto al clasismo se lo puede explicar a nivel de lo que [con la lucha] nos puede dar", ello porque la sociedad se dividiría en clases y en torno del poder estatal. El delegado del PB plantea su desacuerdo con el Programa citado y dice que para muchos trabajadores "fundamentalmente peronistas la cosa no empieza el 29 de mayo [de 1969]". Agrega que "la inclinación hacia la insurrección" fue un "planteo superficial" del SiTraC, porque no se podía ignorar que "la masa se siente identificada con los grupos armados". El comentarista de la entrevista subrayó toda la argumentación del delegado del PB y agregó una marginalia. Allí se advierte que las críticas del entrevistado al Programa y a los grupos de izquierda coinciden con las de los entrevistadores. Ver imagen 6. 
Imagen 6: Entrevista de Pasado y Presente a los delegados de SiTraC, posterior al 26/10/1971.

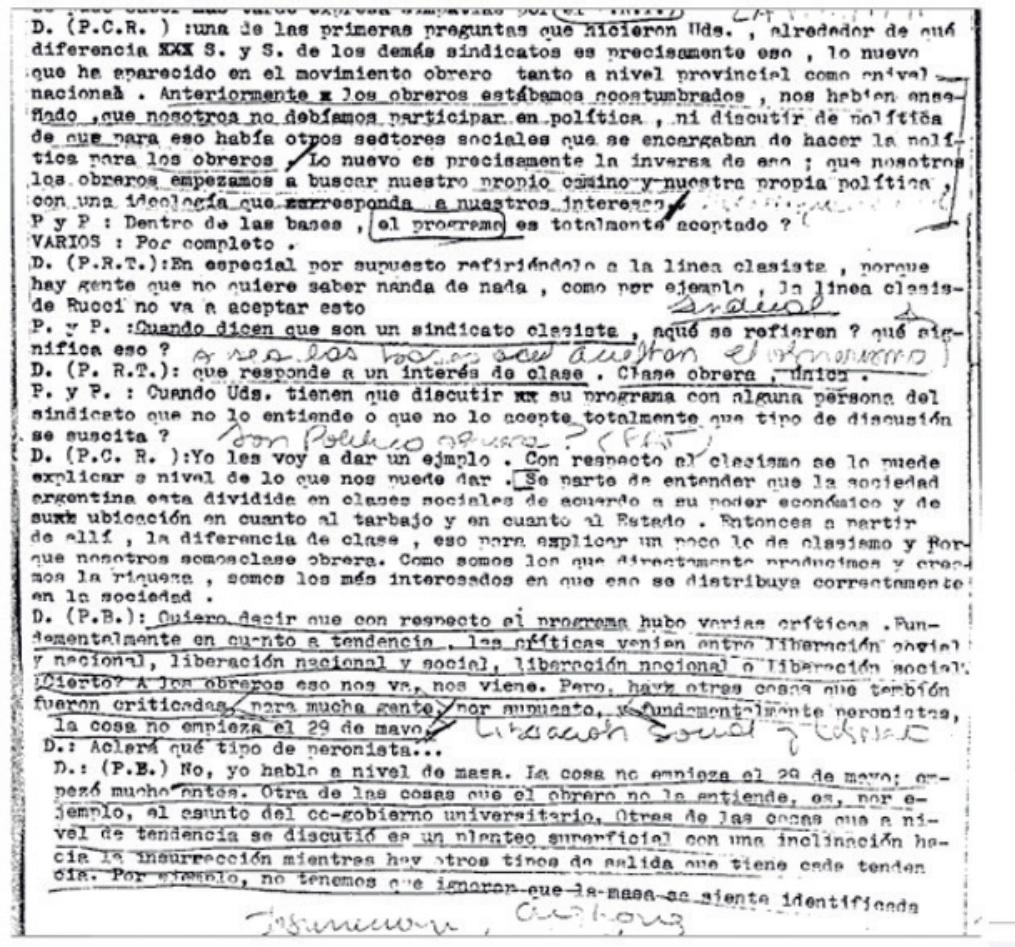

Fuente: Archivo SiTraC, Subarchivo 12, ficha 3.

La oposición ideológica de los entrevistadores con los delegados clasistas reaparece mediante la repregunta "¿Ustedes creen que este Programa es una ayuda, los va a hacer progresar, o que ha creado ciertas dificultades?". El delegado del PCR responde:

No, yo creo que por el contrario, ha abierto un proceso de discusión, que precisamente, como decía el compañero alrededor de un punto fundamental, del tipo de liberación, si es social, solamente, o si es nacional, etc., yo creo que ya ha comenzado a desarrollarse ese tipo de discusión y, por ejemplo, quienes han planteado (como ha salido) la liberación social y nacional; está fundamentado, también, entender la división de clases en la Argentina y que además hoy existe una presión 
económica y política del imperialismo, fundamentalmente yanqui, en la Argentina. Sabemos que las clases dominantes en la Argentina no van a expulsar al imperialismo, por eso se entiende que la liberación tiene que ser primero social porque la única clase que puede expulsar al imperialismo, es la clase obrera. Las clases dominantes se van a aliar con el imperialismo y ya están aliadas. Son socios menores. Por eso entendemos que se desarrolla primero la liberación social como única garantía para expulsar al imperialismo del país. Las clases dominantes concuerdan ideológicamente y hacen alianzas, y hoy son socios menores del imperialismo. (Subarchivo 12, ficha 3).

En este y otros pasajes, la discusión de los entrevistadores y los delegados del PB con los delegados de VC, el PCR y el PRT pasa por la caracterización de la burguesía argentina, por la validez del Programa de SiTraC-SiTraM y por el balance de la derrota. ${ }^{9}$ Sin embargo, llama la atención las breves y escasas intervenciones del delegado alineado con VC. Entre los entrevistados, este es el que más enfatiza la condición democrática de la Comisión Directiva, que se desprendería del amplio apoyo de las bases, y la participación estudiantil y popular en las insurrecciones. Pero además se distingue por proponer que el aislamiento del SiTraC SiTraM se

Los debates sobre las consecuencias de la represión militar y la disolución de los sindicatos clasistas fueron intensos. Por ejemplo, en noviembre de 1971 aparece un documento de dos páginas titulado "Comandismo: una línea de derrota" firmado por el comité central del PCR. Según el PCR esa derrota tuvo su raíz en la influencia del "comandismo", o sea de "los grupos militaristas que practican el terrorismo urbano y su influencia en el movimiento obrero". Estos grupos serían tanto los peronistas (las FAP-PB y otras) como los marxistas (en especial las Fuerzas Argentinas de Liberación y el ERP) que se atribuyen las tareas militares porque no confiarían en la capacidad política insurreccional de las masas obreras, a las que dejarían las tareas de la lucha económica. De allí que para el PCR la derrota de los obreros de FIAT tuvo otras causas que van más allá de la represión militar, una de ellas fue la falta de confianza de las organizaciones "comandistas" que no quisieron llamar a la huelga general, como les propuso el PCR, que tenía una fuerte presencia en las fábricas cordobesas. Las organizaciones "comandistas" lograron influir, según el PCR, sobre la joven comisión directiva de SiTraC-SiTraM que había dado importantísimos pasos hacia la independencia política de los trabajadores respecto de la dirección sindical burguesa y nacionalista. Esos pasos clasistas pudieron darse, según el documento, por la participación masiva de las bases, pero esa participación masiva comenzó a limitarse cuando las organizaciones "comandistas" incidieron sobre la comisión directiva. Dicha influencia se aprovechó de la debilidad de Vanguardia Comunista que conciliaba con las organizaciones armadas, y también aprovechó la debilidad del propio PCR en la fábrica que no enfrentó abiertamente aquella línea "comandista" confiando excesivamente en la espontaneidad de las masas. Cuando avanzó la represión militar se reveló que la política del "comandismo" no habría servido para movilizar a los obreros que sí mostraron disposición a la lucha ("Comandismo: una línea de derrota", Subarchivo 20, ficha 5). 
debió no a la tesis clasista sino al temor que la democratización sindical generó entre las fuerzas sindicales tradicionales. Resalta que esa democratización se logró cuando Córdoba era el epicentro político de la protesta social contra el gobierno militar, pero no evalúa las consecuencias que tuvo la decisión de los clasistas de no aliarse con fuerzas sindicales combativas, como la liderada por Tosco.

En el subarchivo 12, la última "Entrevista de PyP" es realizada a Alfredo "Kuki" Curutchet, el abogado de los clasistas. Este defiende la línea de autonomía de SiTraC-SiTraM respecto de la CGT, y la justifica por la desfavorable relación de fuerzas al interior de esa central. Curutchet admite la influencia en SiTraCSiTraM de los grupos maoístas VC y el PCR, pero entiende que los obreros clasistas condicionaron la política de esas organizaciones y no al revés. También declara que los clasistas fueron los que radicalizaron a los estudiantes. La democracia sindical fue una práctica permanente en las plantas de la FIAT y el famoso Programa constituye una prueba de ello, concluye el abogado.

La transcripción tiene una anotación final, con palabras poco legibles, en la que se puntualizan cuatro reflexiones que se alinean con las posiciones formuladas en el dossier de PyP. Las anotaciones se apoyan en los dichos del delegado del PB y critican "a la izquierda x su sectarismo, su falta de interés en crear conciencia de base"; cuestionan la "estrategia de alianzas" del SiTraC y su falta de un verdadero programa político; y sostienen que el fracaso clasista de SiTraC-SiTraM podría superarse en las elecciones del SMATA a realizarse en 1972. Estas notas muestran la oposición entre las posiciones de PyP y las sostenidas por Fiorito y su grupo. Ambos grupos mantienen diferentes expectativas en el triunfo de la lista Marrón en el SMATA. La Marrón lleva a Rene Salamanca, militante del PCR, como candidato a secretario general y reúne un amplio frente de la izquierda opuesta a los dirigentes peronistas tradicionales. Pero mientras que los intelectuales de PyP apoyan la lista Marrón porque habría superado los límites del clasismo, Fiorito y su grupo la apoyan en tanto retome las experiencias del clasismo. Es más, en 1988 el libro de Natalia Duval presenta como continuidad del clasismo a la lista Marrón de la UOM de Villa Constitución, liderada desde 1972 por Alberto Piccinini y un conjunto de dirigentes de izquierda independientes del peronismo y de las organizaciones armadas.

\section{LAS FOTOGRAFÍAS EN EL ARCHIVO Y EN LA TAPA DEL LIBRO}

Los últimos documentos conservados en la ficha 4 son 28 fotografías. Estas fueron guardadas sin ningún metadato. Conociendo los hechos retratados puede advertirse que la serie no sigue un orden cronológico. Más bien, las 
fotografías parecen haber sido dispuestas como una vía para elevar la conciencia clasista de quienes la transitan. Como venimos insistiendo, los generadores de ese Archivo no lo pensaron solo para que los historiadores examinen el pasado sino también para que quienes apuestan a la lucha emancipatoria puedan recuperar las experiencias de sus predecesores.

Si hasta aquí veníamos analizando documentos escritos que realizaban el paso de los cuerpos al texto, con las fotografías nos encontramos ante los cuerpos en el momento histórico en que fueron fijados para la posteridad. ${ }^{10}$ Con esas fotos la posteridad accede al "referente sin rostro" de la resistencia de los clasistas a la represión, pues solo la última foto de la serie retrata rostros nítidos, los de los dirigentes de SiTraC-SiTraM que encabezaron una columna acompañada por pancartas de las agrupaciones de la nueva izquierda PCR, Comisiones Obreras (ligada a VC), Peronismo de Base, PRT y LAR. Pero esos rostros fueron tachados. Ver imagen 7.

Imagen 7: Fotografías 1970-1971 en carpeta Archivo SiTraC.

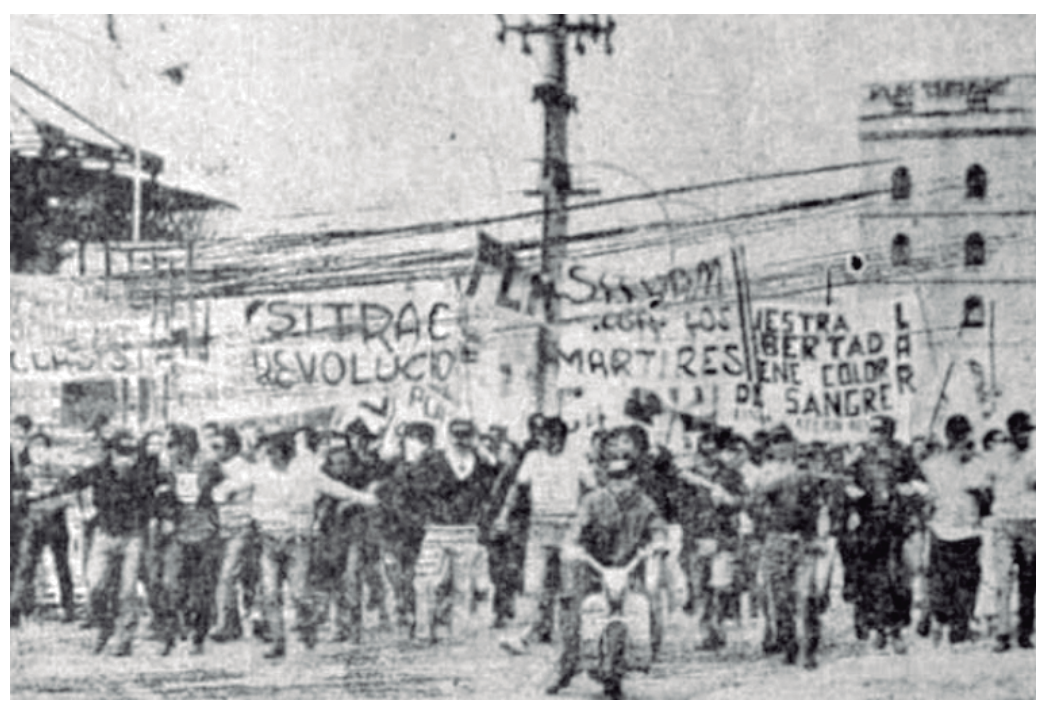

Fuente: Archivo SiTraC, subarchivo 12, ficha 4.

10 Más precisamente, la carpeta de fotografías parece confirmar la observación de John Tagg sobre las fotografías en los archivos, a saber que ellas condensan un sentido que es "ejercido solamente dentro de ciertas prácticas institucionales y relaciones históricas concretas" (11); son puestas, al mismo tiempo, como representación de lo real, reproducción de una experiencia y reformulación del sentido de la fotografía dentro del archivo. 
Seguramente, Fiorito quiso evitar que los aparatos represivos pudieran identificar a esos manifestantes, y con ello, sin planearlo, nos repone hoy el riesgo de muerte que acecha a toda insurrección.

Las primeras doce fotos corresponden a una movilización durante un sepelio. Aunque no estén acompañadas de información, a través de la reconstrucción de época sabemos que se trata de la masiva movilización que acompañó al funeral de Alfredo Cepeda, un joven obrero de FIAT que se transformó en mártir del levantamiento popular del 12 marzo de 1971, conocido como "Ferreyrazo". La policía había ingresado violentamente al Barrio Ferreyra para llevarse el cuerpo de Cepeda y evitar que su sepelio se transformara en una nueva manifestación popular contra el gobierno. Las fotos retratan ese fracaso: el 13 y 14 de marzo miles de hombres, mujeres y niños caminaron o se desplazaron con motos o bicicletas y portando coronas y pancartas despidieron el cuerpo de Cepeda, pero también anunciaron la insurrección del día 15.

Las imágenes del sepelio son sucedidas por las de una multitudinaria toma de la fábrica Concord que realizó el SiTraC. Pero antes, la tristeza del sepelio es interrumpida por una foto de una movilización en la que se cuela el humor cordobés. Al lado de algunas personas se observa una motocicleta y un caballo que obstaculiza el tránsito con las leyendas en su lomo, como consignas en una pancarta, "Barrio Alberdi", "USA" y "Lanusse". Ver imagen 8.

Imagen 8: Fotografías 1970-1971 en carpeta Archivo SiTraC.

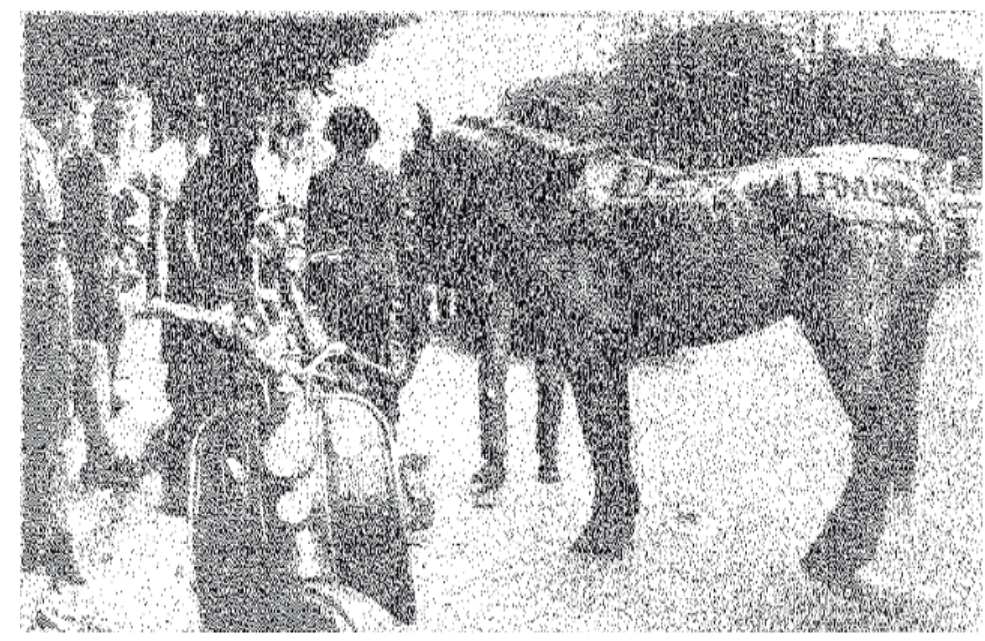

Fuente: Archivo SiTraC, subarchivo 12, ficha 4. 
La ficha 4 permite registrar la complejidad de la apuesta clasista, pues también se conservan fotografías que retratan a los policías que se preparan para reprimir y una en la que se observa a gente corriendo en un descampado. Ésta es acompañada por un recorte periodístico en el que se ve que fue reproducida en un diario, según la fecha agregada a mano, el 23/10/70. Ver imágenes 9 y 10.

Imagen 9: Fotografías 1970-1971, carpeta Archivo SiTraC.

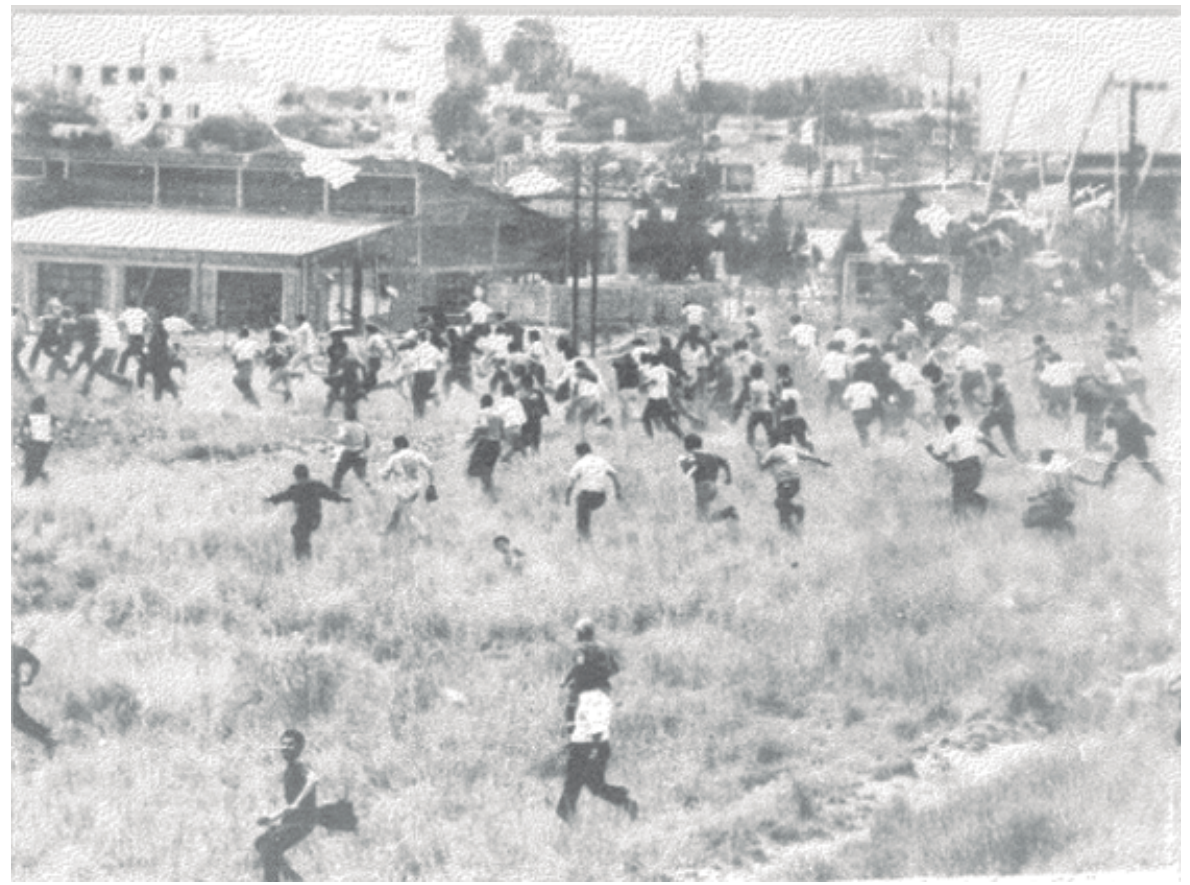

Fuente: Archivo SiTraC, subarchivo 12, ficha 4. 
Imagen 10: Recorte periodístico 23/10/1979. Fotografías 1970-1971.

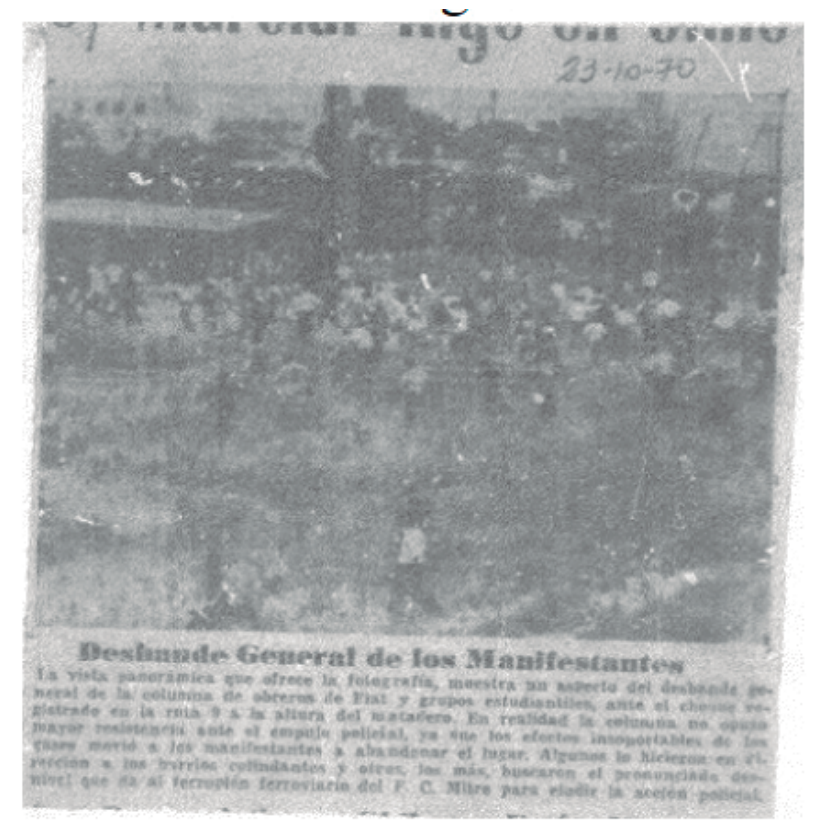

Fuente: Archivo SiTraC, subarchivo 12, ficha 4.

El diario agregó a la foto el título "Desbande General de los Manifestantes" y una aclaración de ese "desbande general de la columna de obreros de FIAT y grupos estudiantiles" que se había producido en el terraplén del ferrocarril Mitre.

Pero fueron las imágenes de la multitud obrera que desplegó la apuesta clasista a partir de tomas de fábricas o manifestaciones callejeras las elegidas para ilustrar los volantes, revistas y libros de la nueva izquierda. En efecto, cuando en 1988 Fiorito publica, bajo el seudónimo de Natalia Duval, Los sindicatos clasistas: SiTraC (1970-1971) elige una imagen de una movilización en la que se ven grandes pancartas con las palabras SiTraC, SiTraM, violencia y revolución. ${ }^{11}$ Ver imagen 11.

11 En 1988, la importante revista cultural porteña Crisis publicó una polémica en torno a SiTraCSiTram. En el número 64 (setiembre de 1988), bajo el título "La izquierda cordobesa", Roberto Reyna criticó los errores de los clasistas, quienes se habrían aislado de Agustín Tosco, desdeñado las tradiciones políticas populares y confundido la tarea sindical con la política. Tales errores habrían facilitado su disolución por el Estado. En el número 67 (enero de 1989), aparece el artículo "Sitrac y Sitram: la autonomía obrera" firmado por Carlos Masera. Masera le reclama a Reyna que 
Imagen 11: Portada de Los sindicatos clasistas: SiTraC (1970-1971).

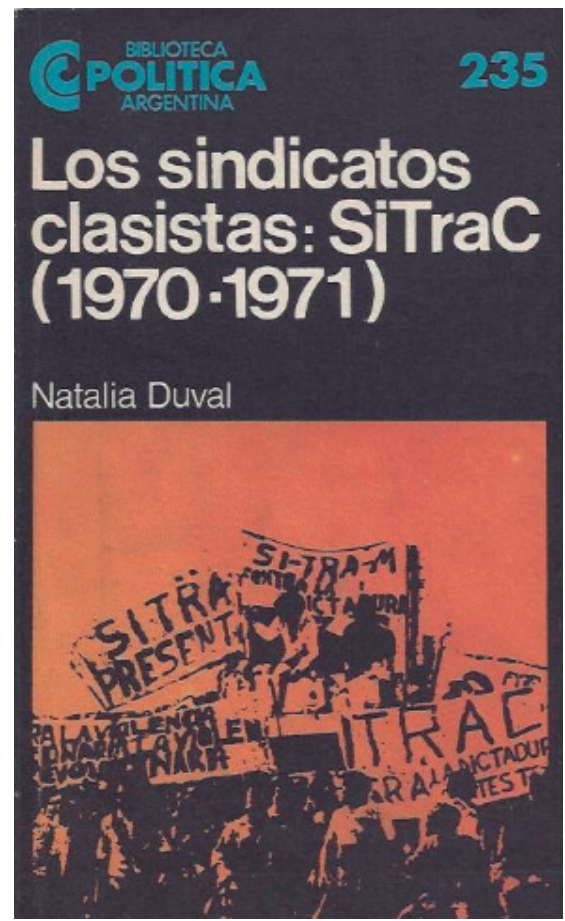

Fuente: Duval, Natalia. Los sindicatos clasistas: SiTraC (1970-1971). CEAL, 1988.

El Archivo SiTraC se muestra una vez más decisivo para descubrir las disputas historiográficas. Allí se conserva la foto original y el contraste con la reproducción de la tapa del libro permite advertir una operación editorial orientada a reforzar la apuesta clasista: la versión en negativo que se reproduce en la tapa es un montaje que logra que se lea mejor la sigla SiTraC, suma una pancarta más del sindicato clasista y recorta la bandera del $\mathrm{PB}$, la agrupación peronista que aparece en la foto conservada en el Archivo.

cite en qué documentos se basa; señala que SiTraC-SiTraM se distanció de la CGT cordobesa pero impulsó el "Ferreyrazo" y el "Viborazo", y que otros sindicatos combativos cordobeses como el SMATA y como Luz y Fuerza, dirigido por Tosco, también fueron disueltos a pesar de no cometer los "errores" adjudicados a los clasistas. Claramente los argumentos de Masera sintetizan los desarrollados en el libro de Duval. 


\section{CONCLUSIÓN}

Nuestro recorrido sugiere al nombre de la persona ficticia Natalia Duval como el sujeto colectivo Archivo de SiTraC, en el que la persona real Susana Fiorito encuentra una autonomía relativa y a su vez una posición de sujeto bajo un colectivo clasista. Sus prácticas archivísticas y editoriales muestran además una toma de distancia de los aparatos estatales para preservar la documentación obrera, y su difusión digital permite valorar sus materiales fuera de las normas tradicionales de la archivística.

En el recorrido del Archivo de SiTraC que propusimos nos interesó precisar los espacios que Susana Fiorito encontró para que allí también se conserve su tesis histórica y su posicionamiento político-intelectual. Así, descubrimos que si en 1984 emprendió el ordenamiento del Archivo y entonces incorporó entrevistas, comentarios a máquina y marginalias, ello respondía a la intención de que la memoria del movimiento obrero preservara no solo las experiencias clasistas sino también la tesis de que un clasismo que impulsara el protagonismo de la base obrera en las insurrecciones mantuviese la independencia política y sindical de la clase trabajadora era la apuesta más interesante de la Nueva Izquierda argentina. Junto a ello esa memoria no debía olvidar los problemas que portaban, por un lado, la apuesta por la lucha armada (el aislamiento militar de la conducción política) y, por el otro, la peronización de los agrupamientos de la nueva izquierda (la subordinación a la dirección política burguesa que representaría Perón), como proponía el grupo Pasado y Presente. Vimos que esa doble oposición coincide con las anotaciones sobre la "derrota" y la peronización de sus colegas que realiza Piglia en su diario personal. Además, las fotos refuerzan esa hipótesis clasista: se ofrecen como los artefactos disponibles para que no solo la prensa, los folletos y los libros de la nueva izquierda prueben la potencia de la insurrección obrera sino también para que el clasismo de la década del ochenta reactive algunas de esas prácticas sindicales.

El Archivo se constituyó en un espacio de discusión y puesta a prueba de la experiencia clasista de la que emergía una organización sindical con una autonomía política que encontraba su límite en la CGT. Para los que apostaron al clasismo, esa organización autónoma llamaba a iniciar la construcción de una organización política que convergiera con experiencias estudiantiles y populares de izquierda. Esa convergencia fracasó cuando en 1973 se nucleó en torno de la consigna "Ni golpe ni elección, revolución!", y la mayoría de la clase obrera votó por la formula peronista. 
En 1988, en la "Introducción" del libro basado en el Archivo SiTraC, Natalia Duval invita a considerar las experiencias de los cordobeses de Luz y Fuerza y SMATA, la Federación Obrera de los Trabajadores de la Industria Azucarera (FOTIA) en Tucumán, la Federación Gráfica Bonaerense, y la UOM Villa Constitución, que también fueron derrotadas entre 1974 y 1975. Duval finaliza la "Introducción" de su libro con un párrafo que recuerda: "Luchar, fracasar, volver a luchar, fracasar, volver a luchar hasta la victoria final: esta es la historia de la clase obrera', habrían consignado los cuerpos orgánicos de SitraC-SiTraM en su boletín del 9 de noviembre de 1971". La cita de Mao le permite formular un futuro anterior como apuesta temporal para resolver la derrota histórica: aun cuando seamos derrotados ya sabremos que la victoria será nuestra. El Archivo SiTraC documenta la irrupción y la derrota en el pasado y ofrece valiosos elementos para el saber y la memoria ligados al recomienzo de emancipación política de las clases trabajadoras.

\section{REFERENCIAS BIBLIOGRÁFICAS}

"Ayuda memoria sobre historia del SiTraC. Recuerdos de Masera (15-7-84)" (Subarchivo12, ficha1).

Artières, Philippe y Dominique Kalifa. "El historiador y los archivos personales: paso a paso". Políticas de la Memoria. Anuario de investigación e información del CeDInCI, no. 13, 2013, pp. 7-11. http://ojs. politicasdelamemoria.cedinci.org/index.php/PM/article/view/133/123

Balvé, Beba, et al. Lucha de calles, lucha de clases. La Rosa Blindada, 1973.

Brennan, James y Mónica Gordillo. Córdoba Rebelde. El Cordobazo, el clasismo, la movilización social. Ediciones de la Campana, 2009.

Brennan, James. El Cordobazo. Las guerras obreras de Córdoba. Sudamericana, 1996.

Caimari, Lila. La vida en el archivo. Goces, tedios y desvios en el oficio de la historia. Siglo XXI, 2017. https://doi.org/10.4067/s071823762019000200253

Camarero, Hernán. A la conquista de la clase obrera. Los comunistas y el mundo del trabajo. Siglo XXI, 2007. https://doi.org/10.1163/156920611x564752

Carnovale, Vera. Los combatientes. Historia del PRT-ERP. Siglo XXI, 2009.

Celentano, Adrián. "Insurrección obrera y compromiso intelectual. Los Libros y Cristianismo y Revolución frente al Cordobazo y el Viborazo". Archivos de Historia del movimiento obrero y la izquierda, no. 4, 2014, pp. 53-75. 
---. "La formación de Vanguardia Comunista y el problema de la construcción del partido revolucionario entre 1965 y 1969". La nueva izquierda. Socialismo, peronismo y revolución (1955-1976), dirigida por María Cristina Tortti et al., Prohistoria, 2014, pp. 83-110. https://doi.org/10.35537/10915/3080

---. "Un análisis de la correspondencia entre los obreros clasistas presos y los intelectuales de la Secretaria de Prensa del SITRAC". Politicas de la Memoria. Anuario de investigación e información del CeDInCI, no. 15, 2015, pp. 97-106. https://doi.org/10.35537/10915/3324

"Comandismo: una línea de derrota", Comité Central del PCR, 11 de noviembre de 1971. (Subarchivo 20, ficha 5)

De Certeau, Michel. La escritura de la historia. Universidad Iberoamericana, 2006.

Domínguez Rubio, Lucas. El anarquismo argentino. Bibliografía, hemerografía $y$ fondos de archivo. CeDInCI-Anarres, 2018.

Doyon, Louise. "La formación del sindicalismo peronista". Nueva Historia Argentina, Tomo 6, dirigida por Alejandro Cattaruzza, Sudamericana, 2002, pp. 357-403.

Duval, Natalia. "Argentina: sindicatos y movimientos de masas". Historia del Movimiento Obrero, no. 95, CEAL 1974.

---. Los sindicatos clasistas: SiTraC (1970-1971). CEAL, 1988, pp. 134-136.

Entrevista a Gregorio Flores, en Los Libros, 21, agosto de 1971.

"Entrevista a Susana Fiorito". El obrerismo de Pasado y Presente. Documentos para un Dossier (no publicado) sobre Sitrac-Sitram, editado por Schmucler, et al., Al margen, 2009.

Fernández Cordero, Laura. Amor y anarquismo. Experiencias pioneras que pensaron y ejercieron la libertad sexual. Siglo XXI, 2017.

Fiorito, Susana y Eugenio Gastiazoro. Ferrocarriles ¿restructuración o entrega? Ediciones MLN, 1965.

Flores, Gregorio. Lecciones de batalla. Razón y revolución, 2016.

---. "Memorias" (subarchivo 12, ficha 3).

http://ojs.politicasdelamemoria.cedinci.org/index.php/PM/article/view/351/331

Fulchieri, Bibiana. El Cordobazo de las mujeres. Las nuestras, 2018.

James, Daniel. Resistencia e integración. Sudamericana, 1999.

Karsz, Saül. “¿Supremacía del individuo y crisis del colectivo?”. Los trabajos y los días. Revista de la cátedra de Historia social de América Latina y 
Argentina de la Facultad de Trabajo Social de la UNLP, no. 4/5, Dic. 2014, pp. 76-89. https://doi.org/10.35537/10915/2108

Laufer, Rodolfo. "Intervención de las izquierdas y politización obrera en SITRAC-SITRAM, la experiencia paradigmática del sindicalismo clasista de los '70'. Izquierdas, no. 49, 2020, pp. 743-766. https://doi. org/10.4067/s0718-50492016000300008

Mignon, Carlos. Córdoba Obrera. El sindicato en la fábrica 1968-1973. Imago Mundi, 2014. https://doi.org/10.14324/111.444.ra.2018.v3.1.008

Nazar, Mariana y Andrés Pak Linares. "El hilo de Ariadna". Políticas de la Memoria. Anuario de investigación e información del CeDInCI, no. 6/7, 2007, pp. 212-218.

Ortiz, María Laura. "Vinculaciones entre la izquierda revolucionaria y la clase obrera en Argentina en la década de 1970: la política sindical clasista de Vanguardia Comunista". Revista Historia Autónoma, no. 13, 2018, pp. 207-224. https://doi.org/10.15366/rha2018.13.011

Pasado y Presente: "El significado de las luchas obreras actuales" en Pasado y Presente, Buenos Aires, Año IV, Nueva Serie, no. 2-3, Julio-diciembre de 1973, pp. 271-282.

Petra, Adriana. "Los documentos particulares como fuentes históricas. La experiencia del CeDInCI con los fondos de archivos de las izquierdas argentinas". Políticas de la Memoria. Anuario de investigación e información del CeDInCI, no. 6/7, 2007, pp. 206-207. https://doi. org/10.4185/rlcs-2016-1084

Piglia, Ricardo, Los diarios de Emilio Renzi. Tomo II. Los años felices. Anagrama, 2016.

"Programa del SiTraC-SiTraM", en Los Libros, 21, agosto de 1971.

Rancière, Jacques. La noche de los proletarios. Un archivo del sueño obrero. Tinta Limón, 2010.

Rivera, Andrés. Ajuste de cuentas. CEAL, 1972.

Schmucler, Héctor, et al., eds. El obrerismo de Pasado y Presente. Documentos para un Dossier (no publicado) sobre Sitrac-Sitram. Al margen, 2009.

Tagg, John. El peso de la representación. Ensayos sobre fotografías e historias. Gustavo Gili, 2005.

Tarcus, Horacio, "Los archivos del movimiento obrero, los movimiento sociales y las izquierdas en la Argentina. Un caso de subdesarrollo cultural". Políticas de la Memoria. Anuario de investigación e información 
del CeDInCI, no. 10/11/12, 2012, pp. 7-18. https://doi.org/10.4000/ nuevomundo.75901

---. Marx en Argentina. Sus primeros lectores obreros, intelectuales y científicos. Siglo XIX, 2007.

Terán, Oscar. Nuestros años sesenta. Puntosur, 1991.

Tortti, María Cristina, directora. La nueva izquierda. Socialismo, peronismo y revolución (1955-1976). Prohistoria, 2014.

Villar, Daniel. "El Cordobazo". La historia popular, 32, 1971. 